\title{
ADH-DHARUURAH WA AL-HAAJJAH DALAM RIBA (Studi Analisis Pemikiran Dr. Wahbah Az-Zuhhailii)
}

\author{
Abdul Ghani \\ Prodi Ekonomi Syariah STIA Alma Ata Yogyakarta \\ Email: gans_achmady@yahoo.co.id
}

\begin{abstract}
World economic system theoretically there are three classifications of the global capitalist economy, a socialist economic system and the economic system of Islam. Empirically third of the economic system is the role of financial institutions either banks or non-bank much earlier unknown in Islam systematically. Domination of banking institutions that can be felt has penetrated into the field of business and corporate, political, social, educational and cultural. So unwittingly activities of human life as if controlled by a banking institution. In its operation there is one thing that is often a debate among Muslim scholars that the application of interest in the world banking system. Legality rate system which is still considered debatable spawned two views are contradictory. On the one hand, the system considers different interest with usury, while others looked the same interest as usury. The majority of Muslim scholars regard the laws of usury is forbidden. However, the prohibition of usury in the view-modernist Muslim groups understood rationally. In this case the element of injustice became a central issue on the prohibition of usury. While the neo-revivalist Muslim group to understand the legal prohibition of riba-formal. This raises the logical consequence that the legal system of interest applied in the banking world have the same portion as usury. Az-Zuhaili seem to have the same view with the neo-revivalist. For Az-standing interest in law Zuhaili same as usury. However Az-Zuhaili look at the prohibition of usury is not absolute and not 'set in stone'. The prohibition of riba can be correlated with the principle of al-dlaruurah wa al-haajah. According usury when faced with conditions very pushy and the urgent need can be allowed with certain restrictions. Az-Zuhaili view that the constituent requires a more in-depth study. As mentioned in the economics of human needs have no limits (red, human needs are endless). In addition the capacity of necessity one can not be measured with standard capabilities someone else. Giving rise to different legal consequences. This has become an important issue in the study of al-dlaruurah wa al-haajah. This study is a library (library research) that is descriptiveanalytic and normative sociological-historical-philosophical. This study used qualitative data analysis in the form of rationalization of deductive and inductive coherently. Definitively al-dlaruurah implies a state of danger or difficulty excessive and sudden lifethreatening human. While al-haajah may imply a need to be realized spontaneously, so that when the need is not met then it would appear negative consequences. The issue of usury in economic activity, which is still being debated, if communicated with the concept of al-dlaruurah wa al-haajah as mentioned Az-Zuhaili memililiki space and capacity of its own. So it can become a legal usury law.
\end{abstract}

Keyword: Adh-Dharuurah, Al Haajjah, Riba 


\section{PENDAHULUAN}

Ketidakstabilan ekonomi dalam dunia perekonomian berdampak pada peningkatan pengangguran dan kemiskinan. Ketidakstabilan ekonomi lebih banyak dipengaruhi oleh faktor inflasi yang terus meningkat, laju suku bunga ril yang tinggi dan flukutuasi valuta asing yang tidak sehat. Krisis ekonomi juga dapat diakibatkan oleh adanya bentuk ketidakadilan sosio-ekonomi dan ketidakmampuan sebagian negara-negara berkembang dalam mencicil bunga utangnya. ${ }^{1}$ Dalam fikih kenyataan ini merupakan bagian dari persoalan sistem ekonomi ribawi yang sering diadopsi oleh sistem ekonomi kapitalis. ${ }^{2}$

Meskipun perekonomian dunia berada dalam kondisi tidak stabil, bagi muslim berpegang pada nilai-nilai al-Qur' an dan al-Hadis dalam menjalankan roda perekonomian merupakan keniscayaan. Dengan maksud tidak terjadi penyimpangan terhadap sistem mu'aamalah syar'iyah dalam aktifitas ekonomi dan bisnis.

Dalam perekonomian masyarakat modern sekarang ini perusahaan maupun lembaga keuangan yang bergerak dalam aktifitas bisnis seperti perseroan, asuransi, koperasi, lembaga perkreditan, lembaga perbankan dengan segala produknya, pasar modal, serta sistem ekonomi internasional yang meliputi investasi, pasar valuta asing, pembayaran cash, open account, commercial bills of exchange, letter of credit, private compensation ${ }^{3}$ terdapat beberapa transaksi yang samar-samar memiliki korelasi dengan sistem bunga dan riba. Di sisi lain aktifitas bisnis tersebut merupakan kebutuhan publik yang tidak dapat dinafikan pada era-globalisasi dan perdagangan bebas saat ini.

Pada tahapan justifikasi sistem bunga konvensional terdapat beberapa orang yang berdalih bahwa dalam kategori riba yang diharamkan hanyalah jenis bunga konsumtif. Yakni bunga yang khusus dibebankan bagi orang yang berpiutang untuk memenuhi kebutuhan hidup individu dan keluarga sehari-hari seperti makan, minum dan pakaian. Hal ini terjadi karena dalam jenis riba tersebut terdapat unsur pemerasan (eksploitasi) terhadap orang yang sedang dalam membutuhkan. ${ }^{4}$ Sementara para pemikir modern seperti Fazlurrahmaan, Muhammad As'ad, Sa'iid an-Najjaar \& Abd. Mun'im anNa'iim menekankan perhatiannya pada aspek moral berupa ketidakadilan ${ }^{5}$ sebagai bentuk pelarangan riba dan mengesampingkan aspek legal-formal. Hal ini sejalan dengan ayat al-Qur'an:

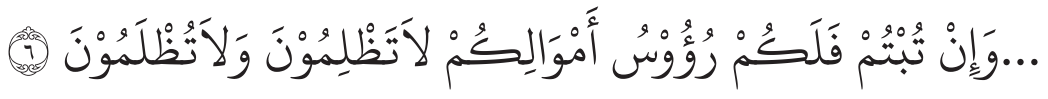

${ }^{1}$ M. Umar Chapra, Sistem Moneter Islam, alih bahasa Ikhwan Abidin Basri (Jakarta: Gema Insani Press, 2000), hlm., xix.

${ }^{2}$ Lebih lengkap baca 'Isa 'Abduh, Wadh' ar-Ribaa fial-Binaa al-Iqtishaadi, cet. ke-1 (Kuwait: Daar al-Buhuuts al- 'Ilmiyah, 1978), hlm., 27- 47.

${ }^{3}$ Nopirin, Ekonomi Internasional, edisi 3 (Yogyakarta: BPFE Yogyakarta, 1999), hlm., 233-237.

${ }^{4}$ Yuusuf al-Qardh\{aawi, Fawaa'id al-Bunuuk Hiya ar-Ribaa al-Haraam, alih bahasa Dr. Setiawan Budi Utomo (Jakarta: Akbar Media Eka Sarana, 2002), hlm., 47.

${ }^{5}$ Abdullah Sa'id, Bank Islam Dan Bunga, Studi Kritis Dan Interpretasi Kontemporer Tentang Riba Dan Bunga, alih bahasa M. Ufuqul Mubin (Jogjakarta: Pustaka Pelajar, 2004), hlm., 73.

${ }^{6}$ Q.S. Al-Baqarah (2) : 279. Berkaitan dengan ayat ini Dr. Wahbah az-Zuhaili memberikan penafsiran, " ...dan jika kamu tidak meninggalkan riba, maka kamu menjadi musuh Allah dan Rasul-Nya, mereka disiksa didunia dan akhirat. Jika kamu bertaubat dari mengambil riba, maka engkau berhak mengambil pokok harta yang telah engaku pinjamkan tanpa menambahi dan mengurangi pokok hartamu, dengan kata lain memakan riba itu bagian dari dosa besar .", lihat Wahbah az-Zuhaili, at-Tafsiir al-Wajiiz (Beirut: Dar al Fikr, t.t), hlm., 48. 
Meski demikian dikalangan sarjana muslim modern terjadi polemik apakah larangan riba sebagaimana yang termaktub dalam al-Qur'an teraplikasikan dalam bunga bank modern. Perbedaan ini nampaknya terfokus pada salah satu dari permasalahan sentral sebagai berikut: Pertama, larangan riba dipahami secara rasional, sehingga unsur ketidakadilan menjadi isu sentral atas pelarangan riba. Kedua, larangan riba dipahami berdasarkan legal-formal sebagaimana yang dikonsepsikan dalam hukum Islam (fikih). Para modernis Islam cenderung pada pandangan yang pertama. Sedangkan kelompok neo-revivalis Islam condong pada pandangan yang terakhir. Neo-revivalis menurut Abdullah Sa'id adalah penafsiran tradisional yang menekankan bahwa setiap bunga adalah riba. ${ }^{7}$

Al-Sanhuri menegaskan bahwa larangan riba dalam semua bentuknya (ribaa jaahiliyah, ribaa nasii' ah, ribaa fadl, ribaa qard) bermuara pada aspek norma, meskipun tingkat larangannya bervariasi. ${ }^{8}$ Pada konteks sekarang meminta bunga (interest) yang berlipat ganda dihukumi sama dengan ribaa al-jaahiliyah (riba yang paling buruk). Atas dasar ini riba dengan segala bentuknya tidak dapat dianggap sah menurut hukum kecuali dalam keadaan terpaksa (daruurah) atau benar-benar membutuhkannya (haajah). Menurut ashSanhuurii bentuk larangan pada ribaa nasii'ah, ribaa fadl, ribaa al-qard tidak lebih hanya untuk mencegah berulangnya praktek riba pada zaman pra-Islam (ribaa aljaahiliyah). Di sisi lain Abdullaah Sa'iid menuturkan bahwa tingkat bunga yang tidak berlipat ganda dapat diperbolehkan untuk sementara waktu, apabila benar-benar membutuhkannya (haajah) tapi dilakukan hanya menurut kadar kebutuhannya. ${ }^{9}$ Menurutnya sebagian ulama tidak mempertimbangkan faktor kebutuhan (haajah) dapat melegitimasi kebolehan bunga (interest). Namun mereka tidak memberi penjelasan tentang berbagai tingkat pelarangan bunga (interest) dengan anggapan semua bentuk bunga adalah riba yang jelas legalitas keharamannya. Arab:

Berkaitan dengan masalah ini Nabi SAW pernah ditanya oleh seorang

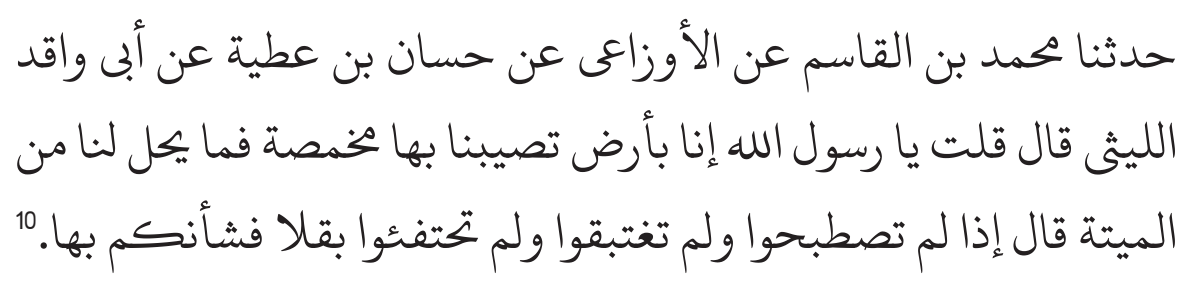

Dalam hal ini Nabi tidak menjelaskan keadaan daruurah secara eksplisit. Sehingga memunculkan pertanyaan apakah kebutuhan (haajah) melakukan transaksi dengan riba termasuk dalam keadaan terpaksa (daruurah) seperti peristiwa yang tersebut dalam hadis tersebut. Kemudian dalam hal pinjam meminjam mungkinkah debitur (peminjam) disamakan dengan orang yang tidak menemukan makanan dan minuman. Abuu Zahrah menegaskan jika

\section{Adh-Dharuu- rah Wa Al- Haajiah 193}

\footnotetext{
${ }^{7}$ Abdullah Sa'ed, Bank Islam dan Bunga, hlm., 72.

${ }^{8}$ As-Sanhuri, Mashaadir al-Haq fii al-Figh al-Islaami (Beirtu: al-Majma' al-'Arabi al-Islami, 1967), III: 241-242.

${ }^{9}$ Abdullaah Sa'ed, Bank Islam dan Bunga, hlm., 78.

${ }^{10}$ Ahmad bin Hambal, Musnad Ahmad, edisi Abi 'Abdillah Muhammad Bin Yazid alQazwaini (Beirut: Dar al-Fikr, 1995 M/1415 H), III: hlm. 605, hadis nomor 20893, “ Kitaab Sanad Al-Anshaar ". Hadis dari al-Auzaa'I dari Hasan bin 'Atiyah dari Waaqid al-Laitsii, hadis ini shahih.
} 
debitur (peminjam) dapat disamakan dengan orang yang dalam keadaan terpaksa, maka kategori daruurah hanya berlaku bagi debitur (peminjam), akan tetapi kategori daruurah tidak berlaku bagi kreditur (pemberi pinjaman). ${ }^{11}$

Dalam kehidupan beragama Islam disyariatkan untuk mencegah kesulitan dan kesempitan. Berkaitan dengan hal tersebut muharramaat (halhal yang diharamkan dalam hukum) terbagi kedalam dua bagian; pertama, haram karena dzat-nya, hal ini tidak boleh dilanggar kecuali karena terpaksa (daruurah); kedua, haram karena faktor lain. Barang haram karena ada faktor lain dapat diperbolehkan karena adanya kebutuhan (haajah) tertentu. ${ }^{12}$ Secara definitive haajah merupakan suatu keadaan dimana seseorang memerlukan sesuatu yang tanpanya ia dapat hidup, namun demikian ia merasa kesulitan. Sementara daruurah merupakan suatu barang yang apabila ditinggal/bahkan tidak ada maka jiwa seseorang dapat terancam atau sebagian anggota tubuhnya akan rusak. Lantas kebutuhan ekonomi terhadap riba apakah termasuk al-haajah asy-syar'iyah atau ad-daruurah asy-syar'iyah yang dapat merusakkan jiwa jika sampai menafikan riba dalam sistem perekonomian.

Wahbah az-Zuhailii (selanjutnya disebut az-Zuhailii) seorang guru besar Universitas Islam Al-Azhar Kairo menegaskan bahwa selama seseorang masih berada dalam stabilitas ekonomi yang normal dan masih memungkinkan untuk melakukan pinjaman tanpa bunga, maka tidak boleh melakukan pinjaman kredit dengan bunga atau jual beli dengan riba. ${ }^{13}$ Baginya bunga dan riba merupakan satu kesatuan yang tak terpisahkan. Di sisi lain az-Zuhailii memperbolehkan pembayaran hutang luar negeri yang disertai dengan bunga-riba ketika dihadapkan dengan kebutuhan (haajah) negara secara umum. ${ }^{14}$ Dengan alasan keterpaksaan (daruurah) dan kebutuhan (haajah) yang mendesak, seseorang dapat diperbolehkan melakukan segala hal yang telah diharamkan secara hukum termasuk dalam persoalan riba. ${ }^{15}$

Namun demikan az-Zuhailii memberikan batasan-batasan tertentu agar seseorang termasuk dalam kategori orang yang benar-benar terpaksa (almudtar). Bahkan dalam perdagangan internasional yang sering mengadopsi sistem riba, az-Zuhailii menekankan adanya rekomendasi dari pemerintah tentang keadaan stabilitas ekonomi Negara, apakah ekonomi Negara benarbenar berada dalam situasi daruurah atau tidak. ${ }^{16}$

Az-Zuhaili menuturkan bahwa kebutuhan dan kepentingan publik (alhaajah al-'aammah) memiliki posisi yang sama dengan keterpaksaan (daruurah). Menurutnya pinjam meminjam (al-qard) secara implisit mengandung unsur riba. Al-qard merupakan jual beli yang dibayarkan untuk masa tertentu. Namun dalam al-qard dapat diperbolehkan karena terdapat kepentingan dan kebutuhan (al-haajah). Nampaknya az-Zuhailii sepaham dengan ashSanhuurii dan Abdullaah Sa'ed bahwa larangan dalam ribaa al-fadl tidak lebih hanya untuk mencegah terjadinya ribaa nasii'ah (riba yang sangat

${ }^{11}$ Muhammad Abuu Zahrah, Buhuuts Fii ar-Ribaa, cet.ke-1 (t.tp; Daar al-Buhuts al- 'Ilmiyah, 1970), hlm. 62.

${ }^{12}$ lihat Ahmad Kaafii, al-Haajah asy-Syar'iyah Huduuduha Wa Q\{awaa'iduhaa (Beirut: Dar al-Kutub al- 'Ilmiyah, 2004), hlm., 36-41.

${ }^{13} \mathrm{Az}-Z$ uhailii, Nazhariyat adh-Dharuurah asy-Syar'iyah, Muqaaranah Ma'a al-Qaanuun alWadh'iy (Beirut: Muassasah al-Risalah, 1982), hlm., 69.

${ }^{14} \mathrm{Az}-Z$ uhailii, Nazhariyat adh-Dharuurah, hlm., 72.

${ }^{15} \mathrm{Ibid}, \mathrm{hlm} ., 261-278$.

${ }^{16} \mathrm{Ibid}$, hlm., 68-72.

Abdul

Ghani

194

JURNAL EKONOMI SYARIAH INDONESIA, Volume V, No.2 Desember 2015 
diharamkan). ${ }^{17}$ Dalam ushul fiqih upaya ini dinamakan saddu zarii'ah. ${ }^{18} \mathrm{Az}-$ Zuhailii mengungkapkan bahwa transaksi bisnis yang terjadi pada lembagalembaga perseroan jika dikaji lebih dalam banyak terdapat kesamaran (syubhaat) yang mengarah pada sistem riba. Namun ia memiliki peranan yang dominan dalam memenuhi kepentingan dan kebutuhan publik. Sehingga jika ditiadakan maka masyarakat akan mengalami kesulitan dalam bidang ekonomi. Karenanya dapat diperbolehkan dengan catatan hanya sekedar untuk menghilangkan kesulitan meskipun didalamnya terdapat unsur riba. Hal ini az-Zuhailiiberpegang pada kaidah ushul fiqih:

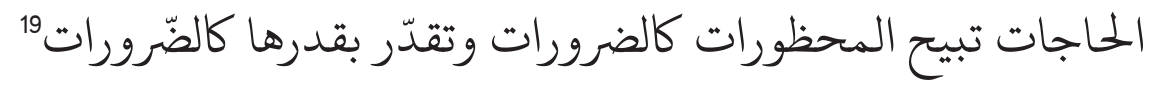

Pandangan inilah yang membuat penyusun tertarik untuk mengangkatnnya sebagai tema skripsi. Beliau merupakan salah salah satu tokoh ulama kontemporer yang telah banyak memberikan kontribusi pemikiran dalam bidang hukum Islam (fiqih). Bagi penyusun pemikiran azZuhailii khusunya dalam konsep ad-daruurah dan al-haajah dalam persoalan riba penting untuk dilakukan kajian yang mendalam. Mengingat dalam satu dasawarsa terakhir sistem perekonomian modern yang melibatkan perusahaan/lembaga-lembaga keuangan yang bergerak dalam aktifitas bisnis banyak menyisakan persoalan hukum yang pelik. Sementara kebutuhan manusia yang tidak terbatas sangat bergantung dengan sistem ekonomi yang ada.

Adapun pokok permasalahan dari penelitian ini adalah; Bagaimana konsepsi az-Zuhailii tentang ad-daruurah wa al-haajah ? Bagaimana az-Zuhailii menerapkan konsep ad-daruurah wa al-haajah dalam riba? Bagaimana relevansi konsep ad-daruurah wa al-haajah yang telah dikonsepsikan az-Zuhaili dengan sistem ekonomi Islam?.

\section{METODE PENELITIAN}

Sebagaimana layaknya karya tulis, penyusun menggunakan beberapa metode untuk memudahkan dalam penyusunan skripsi. Adapun metode penelitian yang dipergunakan adalah sebagai berikut:

${ }^{17}$ Ibid., hlm., 263.

${ }^{18} \mathrm{Saddu} z^{\wedge}$ arii'ah artinya mencegah sampainya suatu hal yang dapat mengakibatkan kerusakan (mafsadaat), karena kerusakan harus dicegah (Az Zuhailii, Ushuul figh al-Islaamy, Beirut: Dar al-Fikr, 1986, III: 873). Saddu $z^{\wedge}$ arii'ah yakni perbuatan yang dilakukan seseorang yang sebelumnya mengandung kemashlahtan tetapi berakhir dengan kerusakan (Rachmat Syafi'I, Ilmu Ushuul Figh, Cet I, Bandung: Pustaka Setia, 1991, hlm., 132). Mengenai prinsip hukum saddu $z^{\wedge}$ arii'ah terdapat ikhtilaf dikalangan ulama. Sebagian menganggapnya sebagai salah satu prinsip hukum yang dapat dijadikan sebagai sarana ijtihad/istimbat hukum. Sebagian yang lain tidak menjadikannya sebagai prinsip hukum dalam ijtihad (istimbaat)). Alii Hasballaah memberikan pengertian bahwa $z^{\wedge}$ arii' $a h$ dapat berupa ucapan atau perbuatan yang dapat menjadi perantara (wasiilah), jalan (t\{\{\{ariiq), yang menyampaikan (mu'adiyan) pada sesuatu yang lain. Maksudnya sesuatu yang asalnya boleh jika dibiarkan dapat merambah menjadi larangan (Alii Hasballaah, Ushuul Al-Tasyrii' Al-Islaamy, Mesir: Dar al-Ma'arif, 1971, hlm., 319). Kemudian Ibnu Qayyim al-Jauziyah melakukan pembagian $z^{\wedge}$ arii'ah kedalam empat bagian: 1. Zarii'ah yang mendorong pada mafsadaat dengan karakteristiknya seperti zina, 2. Zarii'ah yang diperbolehkan sesuai dengan asalnya, terkadang bisa mendatangkan kerusakan dan kemafsadatan, tetapi lebih sering mendatangkan kemaslahatan, 3. Zarii'ah yang mubah akan tetapi lebih sering mendatangkan madharaat, 4 . Zarii'ah yang mubah tetapi sering dijadikan perantara untuk menuju mafsadaat (Ibnu Qayim al-Jauziyah, I'laam al-Muwaqqi'iin, Beirut; Dar al-Fikr, 1977, III: 119-136)

${ }^{19} \mathrm{Az}$ Zuhailii, Nazhariyat adh-Dharuurah asy-Syar'iyah, hlm., 267.

JURNAL EKONOMI SYARIAH INDONESIA, Volume V, No.2 Desember 2015 


\section{Jenis Penelitian}

Penelitian dalam penyusunan skripsi ini adalah penelitian pustaka (library research). Oleh karenanya penyusun melakukan penela'ahan dan penelusuran berbagai literatur ${ }^{20}$ yang memiliki relevansi dengan konsep kajian yang dimaksud.

\section{Model Penelitian}

Penelitian ini menggunakan model penelitian hukum Islam normatifdoktrinal. ${ }^{21}$ Yakni menelaah pandangan az-Zuhailii tentang konsep ad-daruurah dan al-haajah. Kemudian penyusun mengelaborasinya dengan menggunakan teori ilmiyah yang memiliki koherensi dengan kaidah fikih dan ushul fikih.

\section{Teknik pengumpulan data}

Untuk mendapatkan validitas data sebagaimana lazimnya penelitian, penyusun melakukan penggalian data dengan klasifikasi sumber data primer dan data sekunder. ${ }^{22}$ Data Primer, yakni data pokok yang diperoleh dari penela'ahan terhadap ekspresi pemikiran seorang tokoh ${ }^{23}$ dalam hal ini Wahbah az-Zuhailii tentang konsep ad-daruurah dan al-haajah dalam riba. Termasuk dalam kategori ini adalah buku Nazariyat ad-Dharuurah asy-Syar'iyah Muqaaranah ma'a al-Qaanuun al-Wad'iy dan at-Tafsiir al-Muniir keduanya karya Dr. Wahbah az-Zuhailii. Data Sekunder, yakni bahan pustaka tambahan yang merujuk pada data primer baik berupa komentar maupun ringkasan/kutipan ${ }^{24}$, diantaranya buku Nazariyat ad-Dharuurah asy-Syar'iyah Huduuduhaa wa Dhawaabituhaa karya Jamiil Muhammad Bin Mubaarak, alHaajah asy-Syar'iyah Huduuduhaa wa Qawaa'iduhaa karya Ahmad al-Kaafii. Serta buku-buku, majalah, media, jurnal yang memiliki korelasi dengan tema pokok pembahasan skripsi.

\section{Pendekatan Masalah}

Penelitian ini menggunakan pendekatan sociological-histories ${ }^{25}$ dan normative-filosofis. Maksudnya pendekatan yang menekankan pada latar belakang kehidupan dan pemikiran individu sang tokoh dalam hal ini adalah Wahbah az-Zuhailii. Dan menekankan pada penggunaan prinsip-prinsip hukum yang teraplikasikan dalam fikih dan ushul fikih ${ }^{26}$ sebagai norma dan kaidah dasar hukum. ${ }^{27}$

${ }^{20}$ Moh. Nazir, Metode Penelitian (Jakarta: Ghalia Indah, 1985), hlm., 111.

${ }^{21}$ Penelitian hukum Islam normative secara hirarkies dibedakan menjadi tiga, yakni; 1 ) penelitian filosofis (kajian mengenai nilai dasar-dasar hukum Islam); 2) penelitian dokrinal (kajian untuk menemukan doktrin-doktrin atau asas-asas hukum Islam); penelitian ini dibedakan menjadi dua macam, yaitu asas-asas hukum Islam (an-nazhzhariyyaat al-fighiyah) dan kaidahkaidah hukum Islam (al-qawaa'id al-fighiyah) ; 3) penelitian klinis (penemuan hukum syar'i untuk menemukan peraturan-peraturan hukum konkrit (in-concreto/al-ahkaam al-far'iyah). Lihat Syamsul Anwar, Pengembangan Metode Penelitian Hukum Islam, dalam Amin Abdullah et.al., Neo Ushul Figh; Menuju Ijtihad Kontekstual, cet ke-1 (Yogyakarta: Fak. Syari'ah IAIN Sunan Kalijaga, 2004), hlm. 187-193. Bandingkan Amiruddin, dan Zainal Asikin, Pengantar Metode Penelitian Hukum (Jakarta: PT. Raja Grafindo Persada, 2004), hlm., 25.

${ }^{22} \mathrm{Ibid}$. hlm., 30.

${ }^{23}$ Cik Hasan Bisri, Model Penelitian Fiqih (Jakarta: Prenada Media, 2003), hlm., 221

${ }^{24} \mathrm{Ibid}$.

${ }^{25}$ Ibid. hlm., 214.

${ }^{26} \mathrm{Ibid}$. hlm., 221.

${ }^{27}$ Amiruddin, Pengantar Metode Penelitian Hukum, hlm., 118. 


\section{Analisis data ${ }^{28}$}

Dalam kajian penelitian ini penyusun menggunakan analisis data kualitatif ${ }^{29}$ dengan bentuk rasionalisasi deduktif dan induktif.

Bentuk deduktif merupakan proses berfikir dengan metode rasional untuk mendapatkan kebenaran dan kesimpulan yang bersifat individual dari pernyataan yang bersifat umum. ${ }^{30}$ Proses ini digunakan dalam rangka memperoleh gambaran umum mengenai implikasi dalam perkembangan perekonomian modern dari penerapan konsepsi hajah dan dlarurah yang terkait dengan obyek penelitian.

Bentuk induktif merupakan cara berfikir yang berpijak dari fakta-fakta khusus, peristiwa konkrit, kemudian dari pernyataan tersebut disusun generalisasi yang bersifat umum. ${ }^{31}$ Metode ini digunakan dalam rangka memperoleh gambaran secara detail pandangan Wahbah Az-Zuhailii tentang konsep al hajah dan ad dlarurah kemudian ditarik generalisasi yang shifatnya umum.

\section{HASIL DAN PEMBAHASAN}

\section{Penerapan Konsep Ad-daruurah wa al-Haajah Dalam Riba}

Untuk mendapatkan gambaran proses penerapan konsep ad-daruurah dan al-haajah yang diimplementasikan az-Zuhaili dalam riba secara sistematis, penyusun memandang perlu diketahuinya korelasi antara ad-daruurah (keterpaksaan, emergency) dengan riba dan korelasi antara al-haajah (kebutuhan, requirement) dengan riba serta penerapan kaidah fikih yang berhubungan dengan ad-daruurah dan al-haajah (emergency).

\section{Korelasi ad-Dharuurah (emergency) Dengan Riba}

Keadaan darurat (ad-daruurah) sering mendorong manusia untuk melakukan perbuatan-perbuatan yang dilarang syara'. Tindakan-tindakan yang bertentanagn dengan norma baik norma social maupun agama dapat terjadi karena didasari oleh upaya untuk penyelamatan jiwa dan harta benda yang dimiliki. Sebagaimana diketahui perlindungan terhadap jiwa dan harta benda merupakan dua poin penting yang tidak dapat dinafikan dalam kehidupan praksis, dan dalam fikih termasuk bagian dari tujuan disyari'atkannya hukum Islam (maqaaShid asy-syarii'ah). Karena begitu pentingnya mempertahankan eksistensi maqaaShid asy-syari'ah, maka perbuatan apapun dapat dibenarkan meskipun dengan melakukan perbuatan yang pada mulanya diharamkan dalam hukum. Legitimasi ini dibenarkan karena maqaaShid asy-syari'ah merupakan kebutuhan yang bershifat daruuryii(pokok).

Berkaitan dengan dunia perbankan pinjaman kredit tidak hanya terjadi pada aktifitas bisnis/perdagangan, tetapi pemenuhan kebutuhan rumah tangga tidak luput dari campur tangan para rentenir atau kreditur yang memberikan pinjaman bersyarat berupa bunga. ${ }^{32}$.

\section{Adh-Dharuu- rah Wa Al- \\ Haajjah \\ 197}

${ }^{28}$ Analisis data merupakan proses penyederhanaan data ke dalam bentuk yang lebih mudah dibaca dan diinterpretasikan. Lihat Masri, S. dan Sofian E, Metode Penelitian Survei (Jakarta: LP3ES, 1989), hlm., 265.

${ }^{29}$ Dalam penelitian konsep/pemikiran seorang tokoh (fuqaha) seyogyanya menggunakan paradigma penelitian kualitatif. Lihat Cik Hasan Bisri, Model Penelitian Fiqih, hlm., 190.

${ }^{30}$ Heru Sudarsono, Konsep Ekonomi Islam Suatu Pengantar, cet I (Yogyakarta: Ekonisia, 2004), hlm., 70.

${ }^{31}$ Marzuki, Metodologi Riset (Yogyakarta: Ekonosia, 2005), hlm., 4.

${ }^{32}$ Suhrawardi membedakan antara rente dan riba, hal tersebut dilihat dari aktifitas dunia perbankan. Ia beranggapan bahwa rente merupakan keuntungan yang diperoleh pihak bank 


\section{Korelasi al-haajah (kebutuhan) dengan Riba}

Al-haajah (kebutuhan) sebagaimana dijelaskan pada bab sebelumnya baik dalam pandangan ulama tafsir maupun ulama fikih yang meliputi ulama klasik dan kontemporer mengandung pengertian adanya kebutuhan hidup manusia yang komplek, baik kebutuhan individu maupun kebutuhan masyarakat secara umum. Tak dapat disangkal lagi kebutuhan akan harta merupakan suatu keniscayaan. Sebagaimana an-Nabhani berpandangan bahwa kebutuhan akan harta merupakan upaya untuk menyambung hidup, ${ }^{33}$ karena hidup menurutnya merupakan hak asasi setiap orang. Untuk memenuhi kebutuhan hidup tentu harus ada upaya yang dilakukan manusia sesuai dengan kemampuan dan keahlian (skill) yang mereka miliki. ${ }^{34}$ Dapat juga dikatakan manusia harus bekerja sesuai dengan profesinya masingmasing.

Fakta sejarah (the real of history) membuktikan tindakan masyarakat baik masyarakat jahiliyah maupun masyarakat modern_untuk memenuhi kebutuhan hidupnya tidak lepas dari aktifitas perdagangan/jual beli (al-bai') dan pinjaman/hutang piutang (al-qard) yang dalam term ekonomi disebut juga pinjaman kredit. Seiring dengan perkembangan zaman kedua aktifitas ini secara natural menjadi profesi tersendiri. Sehingga dalam dunia perdagangan kita akan menemukan term pedagang dan pembeli, sedangkan dalam pinjaman kredit akan ditemukan term kreditur dan debitur. Kedua pihak saling berkompetisi untuk dapat memenuhi kebutuhannya masing-masing.

Dalam konteks masyarakat modern aktifitas perdagangan (al-bai') terkadang bergantung pada pinjaman kredit (al-gard). Hal ini terjadi baik pada perdagangan sekala kecil maupun perdagangan sekala besar. Dalam rangka mengembangkan usahanya pihak pedagang/perusahaan berupaya mendapatkan modal usaha antara lain dengan melakukan pinjaman kredit kepada pemilik modal (selanjutnya disebut kreditur). Kreditur dapat berupa lembaga maupun perorangan. Sebagai contoh, dalam perdagangan kecil bank-bank pemerintah menawarkan beberapa kredit dengan bunga rendah. Namun di satu sisi pihak pedagang (selanjutnya disebut debitur) banyak mengalami kesulitan untuk mengambil kredit tersebut karena tidak dapat memenuhi persyaratan administrasi. Kondisi ini memunculkan para rentenir (pengambil bunga uang pinjaman; riba) untuk menawarkan jasa kredit dengan persyaratan yang mudah tapi dengan bunga yang tinggi. Karena

karena jasanya telah meminjamkan uang untuk memperlancar kegiatan usaha perusahaan/ orang yang telah meminjam uang tersebut. Dengan bantuan bank yang telah meminjamkan uang tersebut, usaha perusahaanya telah semakin maju, dan keuntungan yang diperolehnya pun semakin besar. Atas dasar pemberian bantuan keuntungan tersebut, bank memperoleh bagian keuntungan, sedangkan mengenai keuntungan yang diperoleh bank tersebut telah ditetapkan terlebih dahulu dalam akad kredit yang telah disepakati.

Sedangkan kegiatan riba dalam prakteknya merupakan pemerasan yang dilakukan terhadap si miskin yang pada dasarnya memerlukan pertolongan agar dapat melepaskan diri dari kesulitan hidupnya, terutama untuk memenuhi kebutuhan pokoknya. Namun sebaliknya tukang riba datang menawarkan jasa dengan cara meminjamkan uang kepada si miskin tersebut dengan ketenutan uang harus beranak (berbunga). Karena si miskin tidak mampu membayar hutang tepat pada waktunya maka bunga pinjaman terus bertambah dan seterusnya. Selanjutnya Suhrawardi mengemukakan bahwa rente lebih bersifat produktif, sementara riba lebih bersifat konsumtif. Lihat Suhrawardi K Lubis, Hukum Ekonomi Islam, cet ke-3 (Jakarta: Sinar Grafika, 2004), hlm. 27-28.

${ }^{33}$ An-Nabhaani, An-Nizhaam al-iqtishaadi fii al-Islaam, alih bahasa Maghfur Wahid, cet ke-4 (Surabaya: Risalah Gusti, 1999), hlm., 118.

${ }^{34} \mathrm{Ibid}$.

\section{Abdul \\ Ghani}

198

JURNAL EKONOMI SYARIAH INDONESIA, Volume V, No.2 Desember 2015 
membutuhkan suplay dana untuk mempertahankan aktifitas usahanya debitur tetap melakukan pinjaman kredit tersebut meski secara ekonomis dirasakannya berat.

Secara materil rentenir/kreditur tidak hanya memberikan dukungan finansial terhadap aktifitas perdagangan kecil tetapi juga perdagangan dengan skala besar. Sehingga seakan-akan tanpa peranan rentenir/kreditur para pedagang kecil dapat bangkrut atau aktifitas perdagangan besar akan mengalami stagnasi..$^{35}$

Dengan demikian rentenir/kreditur memiliki peran ganda yang ambivalen; yakni; Pertama, mengeksploitasi pihak debitur yang sedang membutuhkan modal dengan menarik keuntungan berupa bunga pinjaman. Kedua, sebagai agen pembangunan dan perkembangan karena secara tidak langsung ikut membantu pemerintah dalam menopang dinamika perdagangan dengan memberikan suplay financial kepada masyarakat secara langsung.

Dari uraian di atas aktifitas ekonomi yang dimainkan oleh rentenir atau kreditur dalam pandangan fikih jelas mengandung unsur riba. Karena terdapat tambahan yang disyaratkan dan disepakati bersama. Namun faktor kebutuhan yang muncul dari pihak debitur keberadaannya tidak bisa dinafikan.

Secara spesifik terdapat beberapa kaidah fikih berkaitan dengan konsep ad-daruurah dan al-haajah yang diterapkan az-Zuhailii untuk menganalisis dan menjustifikasi berlakunya system ekonomi ribawi.

\section{Aplikasi Kaidah Fikih Yang Berhubungan Dengan ad-Dharuurah dan al- Haajah Dalam Riba}

Secara substansi terdapat perbedaan antara term al-haajah dengan term ad-daruurah. Namun beberapa ulama baik klasik maupun kontemporer dalam menyebutkan term ad-daruurah selalu diikuti dengan term al-haajah. Begitu juga sebaliknya ketika menyebutkan term al-haajah mereka selalu mengaitkannya dengan term al-haajah. Jalaaluddin ashSuyuutii, misalnya ketika membahas kaidah ad-daruuraat tubiihu al-mahz\}uuraat (keadaan darurat dapat dijadikan sebagai sarana legitimasi untuk melanggar laranganlarangan syara'), ashSuyuutii mengemukakan bahwa ketika barang haram telah merambah ke segala penjuru sampai tidak ditemukan barang halal maka boleh melakukannya sesuai dengan kebutuhannya, tidak hanya sebatas darurat. ${ }^{36}$ Demikian juga Jamiil Muhammad bin Mubaarak sebagai ulama mutaakhirin dalam pembahasan ad-daruurah selalu dikaitkan dengan term al-haajah. Sedangkan Ahmad al-Kaafi dalam pembahasan teori al-haajah juga mengaitkannya dengan term ad-daruurah beserta kaidah-kaidahnya. Hal ini membuktikan bahwa antara al-haajah dengan ad-daruurah memiliki keterkaitann yang sangat erat. Bahkan keterkaitan tersebut nampaknya tidak bisa dipisahkan dalam pembahasan antara yang satu dengan yang lainnya.

Dalam hal ini az-Zuhailii sendiri ketika membahas ad-daruurah selalu mengaitkannya dengan term al-haajah. ${ }^{37}$ Namun secara teoritis az-Zuhailii memposisikan al-haajah sebagai turunan dari keberadaan ad-daruurah. Hal ini dapat dilihat dari pemetaan beliau tentang kaidah-kaidah yang berhubungan

Adh-Dharuu-
rah Wa Al-
Haajjah
199

${ }^{35}$ Heru Nugroho, Uang Rentenir dan Hutang Piutang di Jawa, cet ke-1 (Yogyakarta : Pustaka Pelajar, 2001), hlm. 36.

${ }^{36}$ As-Suyuut\{ii, al-Asybah wa an-Nazhaair, hlm. 60.

${ }^{37}$ Lihat dalam Az-Zuhaili, Nazhariyah adh-dharuurah al-syar'iyah, hlm. 72, 159, 165, 170,172, 173. lihat juga dalam karya beliau at-Tamwiil wa suuq al-awraaq al-maaliyah, cet ke-1 (Damskus: Dar al-Maktaby, 1997), hlm. 8.

JURNAL EKONOMI SYARIAH INDONESIA, Volume V, No.2 Desember 2015 
dengan konsep ad-daruurah. Dari delapan kaidah yang berhubungan dengan ad-daruurah, hanya satu kaidah yang ia sebutkan sebagai dasar untuk membahas konsep al-haajah.

\section{Kaidah fikih yang berhubungan dengan konsep ad-daruurah}

Dari beberapa kaidah yang dideskripsikan dalam pembahasan konsep ad-daruurah hanya satu kaidah yang dipergunakan az-Zuhaili untuk menyinggung poko persoalan riba, yakni :

$$
\text { الضرورات تبيح المحظورات }
$$

Terhadap kaidah ini az-Zuhailii memberikan interpretasi bahwa semua keadaan darurat atau kebutuhan yang sangat penting (al-haajah asy-syadiidah) dapat dijadikan sebagai alat legitimasi dalam melakukan larangan syar $>$ i. Bahkan setiap larangan dalam Islam selain perbuatan kufur, membunuh, dan zina diperbolehkan melakukannya ketika benar-benar dalam situasi darurat (emergency, necessity).

Kaidah ini memang pada dasarnya melegitimasi segala bentuk larangan syar $>$, namun kaidah tersebut tidak bisa dijadikan sebagai alat pembenaran secara mutlak untuk melanggar larangan-larangan syara>. Seandainya kaidah ini tidak dibatasi dengan kaidah lain yang lebih populis maka tindakantindakan kejahatan yang mengatasnamakan daruurat akan sering terjadi. Oleh karena itu kaidah ini perlu dibatasi dengan satu kaidah yang lebih spesifik, yaitu;

$$
\text { ما أبيح للضرورة يقدر بقدرهات38 }
$$

Maksud kaidah ini sesuatu (baik materil/immaterial) yang diperbolekan karena daruurat harus disesuaikan dengan kadar daruurahnya. Dengan adanya kaidah ini sikap kesewenang wenangan dapat dinetralisir. Bagaimanapun juga kewenangan yang diberikan kepada seseorang apabila tidak diberikan batasan-batasan maka yang timbul justru kekacauan atau kerusakan (darar) itu sendiri.

Kaidah ini juga bersumber dari sebuah hadis Nabi SAW:

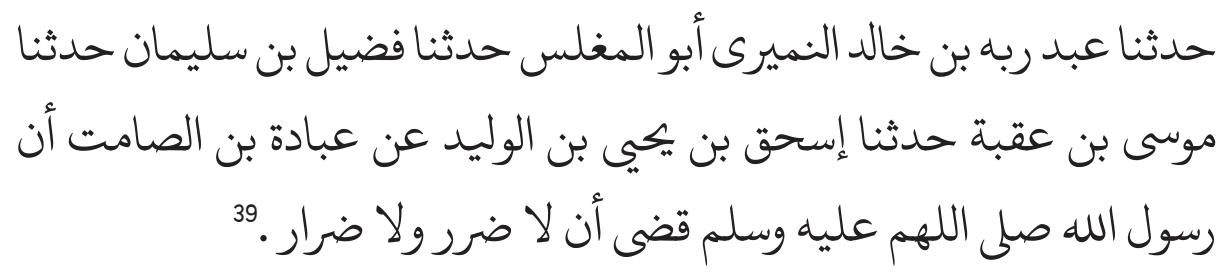

Oleh karena itu Dr.'Abdullah al-'Araby memberikan pernyataan bahwa dalam kondisi saat ini peran bank konvensional yang tidak lepas dari system riba memiliki peran yang sangat dominan. Secara impilisit ia mengatakan Bank

${ }^{38} \mathrm{Abd}$. Haq dkk, Formulasi Nalar Fikih; Telaah Kaidah Fiqih Konseptual, cet. Ke-2 (Surabaya: Khalista, 2006), I: 226.

${ }^{39}$ Abii 'Abdullaah Muhammad bin Yaziid al-Qazwaini, Sunan Ibn Maajah, Edisi Abii 'Abdillaah Muhammad Bin Yaziid Al-Qazwainii (Beirut: Dar al-Fikr, 1995 M/1415 H), I: 736, Hadis Nomor 2340, “ Kitaab al-Ahkaam”, “ Baab Man Banaa Fi Haqqihi Maa Yadhurru Bi Jaarihii." Hadis dari ‘Ubaadah bin ash-Shamit, hadis ini sahih, karena perawi-perawinya nya memiliki tingkatan tsiqah dan shadduuq.

Abdul
Ghani

200

JURNAL EKONOMI SYARIAH INDONESIA, Volume V, No.2 Desember 2015 
berperan dalam pembiayaan aktifitas produksi dan impor barang dari suatu Negara ke Negara lain. Sementara pembayaran dilakukan secara otomatis harus melalui bank. Di sisi lain hanya Negara Islam yang berhak melakukan pelarangan sistem riba dalam perbankan. Sedangkan dalam aktifitas ekonomi dunia yang meliputi perdagangan luar negeri baik berupa ekspor-impor barang maupun pinjaman utang luar negeri tentunya melibatkan beberapa Negara yang tidak terbatas pada Negara Islam. Sehingga tidak ada alternative lain untuk menghindari bunga riba dalam perdagangan tersebut dan dengan sendirinya membiarkan sistem riba bercampur dengan sistem Islami (sistem ekonomi yang tidak menggunakan system bunga/riba). ${ }^{40}$ Oleh karena itu riba dengan alasan tersebut dapat menjadi legal.

Sebagian ulama Hanafiyah memperbolehkan mengambil harta orang kafir harbiy meski dengan jalan yang bertentangan dengan syara seperti riba. Bagi mereka pada dasarnya harta tersebut diambil dengan keridaanya. Secara implisit Hanafiyah menuturkan bahwa kaidah ini dapat dijadikan sebagai legitimasi untuk pembenaran melakukan pinjaman yang berbunga bagi orang yang membutuhkan (al-muhtaaj). Karenanya melakukan transaksi dengan bank-bank konvensional yang menggunakan sistem bunga riba menurutnya tidak menjadi persoalan. ${ }^{41}$

Berdasarkan kaidah ini jika suatu barang haram telah menyebar sampai tidak ditemukan lagi barang halal kecuali hanya sedikit maka boleh menggunakan sesuatu yang dibutuhkan manusia bahkan tidak terbatas hanya sekedar menutupi darurat namun boleh melakukannya sesuai dengan kebutuhan. Dengan alasan ini pula sebagian ulama banyak yang mengangap bahwa riba yang diharamkan dalam Islam hanya riba yang terdapat dalam pinjaman konsumtif. Sedangkan dalam pinjaman produktif riba diperbolehkan. ${ }^{42}$

Berkaitan dengan kaidah ini az-Zuhailii bersikeras melarang seseorang untuk bekerja di bank-bank konvensional kecuali dalam keadaan darurat. Menurutnya bank-bank konvensional tidak lepas dari pemberlakuan sistem riba. ${ }^{43}$ Dalam keadaan bagaimanapun bunga dalam perbankan bagi az-Zuhailii sama dengan riba dan diharamkan dalam Islam. Hal ini tidak lain demi untuk menjaga kehati-hatian (ihtiyaat) dalam menerapkan hukum Islam. Meskipun dengan alasan darurat riba menjadi legal, namun bagi az-Zuhailii porsi darurat yang dimaksud sangat jarang terjadi di zaman modern saat ini. ${ }^{44}$

\section{Kaidah Yang Berhubungan Dengan al-Haajah}

Landasan kaidah fikih yang diungkapkan az-Zuhailii dalam menyinggung persoalan riba adalah kaidah berikut;

$$
\text { الحاجة العامة او الخاصة تنزل منزلة الضرورة }
$$

\section{Adh-Dharuu- rah Wa Al- Haajjah 201}

\footnotetext{
${ }^{40}$ Jamiil M. Mubaarak, Nazhariyat adh-Dharuurah asy-Syar'iyah, hlm. 463.

${ }^{41}$ Az-Zuhailii, Nazhariyah adh-Dharuurah, hlm. 235.

${ }^{42}$ Ibid., hlm. 236.

${ }^{43}$ Az-Zuhailii, Nazhariyah adh-Dharuurah, hlm. 228. Az-Zuhailii berpandangan bahwa bunga bank dan riba merupakan dua suku kata yang memiliki kesamaan arti. Bandingkan dalam al-Figh al-Islaam wa adillatuhuu, II: 3745.

${ }^{44}$ Ibid. hlm. 236
} 
Terdapat beberapa kaidah fikih yang memiliki pengertian sama dengan kaidah tersebut ${ }^{45}$, antara lain: al-haajatu tanzilu manzilata ad-daruurat ${ }^{46}$ (hajah sama dengan posisi darurah), al-haajat tanzilu manzilata ad-daruurah, 'aammatan kaanat aw khaaShShatan (hajah sama dengan posisi dlarurah, baik hajah yang bersifat umum atau hajah yang bersifat khusus), al-haajah al-khaaShShah tubiihu al-mahzuur (hajah yang bersifat khusus dapat dapat melegitimasi berlakunya barang-barang haram). Kaidah yang pertama mencakup kebutuhan publik (haajah'aammah) dan kebutuhan privat (haajah khaaShShah).

Kebutuhan (al-haajah) baik kebutuhan publik (al-haajah al-'aammah) maupun kebutuhan privat (al-haajah al-khaaShShah) dapat berpengaruh terhadap perubahan hukum sama halnya dengan al-daruurah. Sehingga diperbolehkan melanggar larangan dan meninggalkan kewajiban. Akan tetapi al-haajah lebih umum dari pada ad-daruurah. Secara empiris al-haajah meliputi setiap keadaan sulit atau mendesak yang tidak bisa ditolerir. Sementara addaruurah sudah mengarah kepada bahaya yang dapat mengancam jiwa. ${ }^{47}$

Andaikata hajah yang bersifat umum tidak diperhatikan maka ia akan berimbas pada individu-individu yang berada di dalamnya. Akhirnya hal itu akan menyebabkan setiap komponen masyarakat ditimpa oleh daruurat lebih besar daripada kadar daruurat yang hanya dialami oleh satu orang (baca: satu orang yang hajahnya tak terpenuhi). Dasar pemikiran inilah yang melatarabelakangi kebutuhan universal (hajah 'ammah) lebih diutamakan daripada kebutuhan individual (hajat khassah). Dengan demikian hajat 'ammah dalam sub kaidah ini sudah nyaris menyamai daruurat. Dengan makna bahwa hajah yang dimaksud dalam kaidah ini hajah yang sudah mendekati tingkat daruurat.

Berdasarkan kaidah ini az-Zuhailii berkesimpulan bahwa dalam hutang piutang pada hakekatnya memiliki unsur riba. Hutang piutang secara tersirat nampak seperti jual beli yang barangnya diserahkan secara tempo. Hal ini jelas mengandung unsur riba yang diharamkan. Namun hutang piutang merupakan kebutuhan yang tidak bisa dihindarkan dan sudah menjadi tradisi umum dalam kehidupan bermasyarakat di berbagai negara. Sehingga atas dasar ini persoalan riba diperbolehkan.

Berkaitan dengan kaidah ini nampaknya az-Zuhailii sependapat dengan Ibnu al-Qayyim al-Jauziyah yang menyatakan pembenaran ribaa al-fadl. AlJauziyah mengungkapkan bahwa pada hakekatnya ribaa al-fadl diharamkan hanya untuk mencegah terjadinya ribaa al-nasii'ah. ${ }^{48}$ Pendapat ini diambilnya berdasarkan hadis Nabi yang memperbolehkan jual beli 'araayaa ${ }^{49}$ (tukar menukar kurma basah dengan kurma kering). Sebagaimana diketahui pada masa Nabi sering terjadi jual beli 'araaya, secara definitif jual beli tersebut syarat dengan unsur riba. Akan tetapi untuk memenuhi kebutuhan seseorang Nabi memperbolehkan jual beli tersebut. Hal ini terlihat dalam hadis Nabi SAW sebagai berikut:

\footnotetext{
${ }^{45} \mathrm{Ahmad}$ Kaafi, al-Haajah asy-Syar'iyah, hlm. 175.

${ }^{46}$ Alii Hasballaah, Ushuul at-Tasyrii' al-Islaami, hlm. 308

${ }^{47}$ Ibid., hlm., 261.

${ }^{48}$ Ibnu al-Qayyim, I'laam al-Muwaqqi'iin, II: 140.

${ }^{49 \prime}$ A raayaa adalah bentuk jamak dari 'ariyah yang artinya pohon kurma dan maknanya yaitu pemberian buah kurma yang masih berada di pohonnya. Lihat Syaikh 'Isya Bin Ibrahim al-Duwaisyi, Al-Buyuu' al-Jaaiz minhaa wa al-mamnuu', alih bahasa Ruslan Nurhadi, cet ke-1 (Bogor: Daar Ibni Khuzaimah, 2002), hlm. 64-67.
}

\section{Abdul \\ Ghani}

202

JURNAL EKONOMI SYARIAH INDONESIA, Volume V, No.2 Desember 2015 


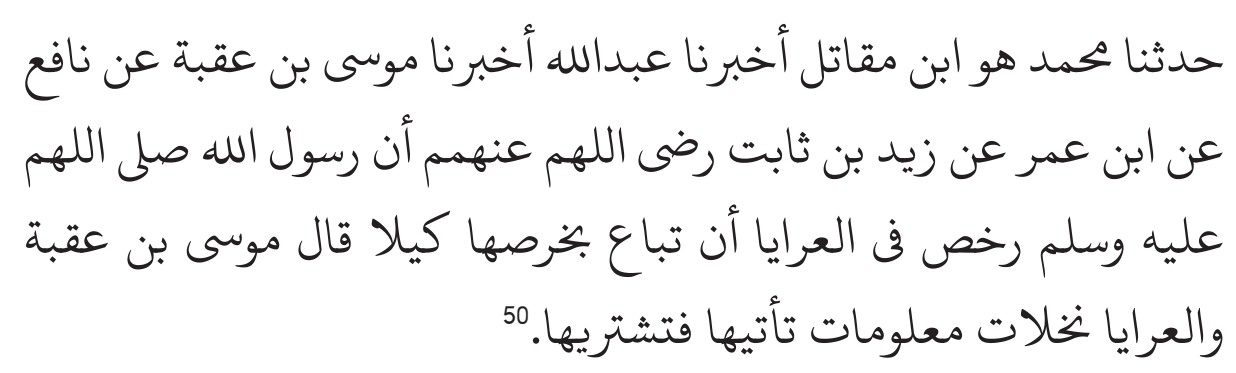

\section{Relevansi Konsep Ad-daruurah wa al-haajah Dengan Sistem Ekonomi Islam}

Dalam ekonomi dikenal dengan term kebutuhan (haajah) tidak terbatas dan sumber daya yang terbatas. Ekonomi Islam berbeda dengan ekonomi konvensional. Dalam ekonomi Islam kebutuhan (need; hajah) dibatasi oleh sumber daya yang tidak terbatas, sementara keperluan yang tidak terbatas bukan lagi termasuk kebutuhan tetapi keinginan. Ekonomi dalam pandangan sistem ekonomi konvensional disebutkan sebagai ilmu yang mempelajari kebutuhan manusia yang tidak terbatas dengan sumber daya yang terbatas. Sedangkan sistem ekonomi Islam memandang bahwa kebutuhan manusia sangat terbatas karena pemenuhannya disesuaikan dengan kapasitas jasmani manusia ${ }^{51}$ seperti makan, minum dan sebagainya. Sebagai contoh seseorang yang sudah merasakan kenyang dengan tiga piring nasi dan sayuran dalam sehari maka manusia tidak akan makan lagi. Karena jika ia makan lagi tentu kapasitas perutnya tidak bisa menampung dan jika dipaksakan makanan tidak terasa enak dan bahkan terasa ingin muntah. Contoh sederhana ini menunjukkan bahwa kebutuhan sebenarnya terbatas. Sedangkan yang tidak terbatas adalah keinginan, karena keinginan merupakan wujud pemenuhan manusia yang dipengaruhi faktor dari luar dirinya (preferensi) seperti keluarga dan lingkungan, dan/atau promosi, iklan, sinetron, film, dll

Secara prinsipil terdapat perbedaan antara ekonomi Islam dengan ekonomi konvensional. Namun letak perbedaan tersebut bukan pada sisi teknis penggunaan metodologinya tetapi lebih menekankan pada perbedaan dasar dari cara berfikir tentang masalah manusia. Dalam hal ini Bagir Sadr menyatakan bahwa perbedaan ekonomi Islam dengan ekonomi konvensioanal terletak pada filosofinya bukan pada sainsnya. ${ }^{52}$ Secara filosofis ekonomi Islam bertolak pada prinsip keadilan, sedangkan keadilan sendiri tidak akan terwujud tanpa adanya moral transendental. Karena dalam pembangunan yang berkeadilan menghendaki adanya pertanggungjawaban kepada Tuhan termasuk dalam pembangnan ekonomi. ${ }^{53} \mathrm{Hal}$ ini sejalan dengan definisi ekonomi yang dikemukakan Hasanuzaman yang menekankan adanya keadilan, Ia menyatakan ekonomi Islam merupakan pengetahuan dan aplikasi dari anjuran dan aturan syari'ah yang mencegah ketidakadilan dalam

\section{Adh-Dharuu- rah Wa Al- \\ Haajjah 203}

${ }^{50}$ Al-Bukhaari, Shahiih al-Bukhaarii (Surabaya; Maktabah Daar al-Kutub al-'Arabiyah, t.t), II: 23, "Kitaab al-Buyuu' “, "Baab Tafsiir al-'Araayaa”. " Hadis dari Musa bin 'Uqbah dari Naafi' dari Ibn 'Umar dari Zaid bin $S^{\wedge} \#$ abit RA, hadis ini sanadnya sahih, perawinya memiliki tingkatan siqah.

${ }^{51}$ Heri Sudarsono, Konsep Ekonomi Islam, Suatu Pengantar, cet ke-3 (Yogyakarta: Ekonisia, 2004), hlm. 11.

${ }^{52}$ Baqir Sadr, Iqtisaduna, dalam Heri Sudarsono, hlm. 13.

${ }^{53}$ Masyhuri, Landasan Filosofis Ekonomi Islam, Dalam Teori Ekonomi Dalam Islam (Yogyakarta: Kreasi Wacana, 20005), hlm. 53.

JURNAL EKONOMI SYARIAH INDONESIA, Volume V, No.2 Desember 2015 
memperoleh sumberdaya-sumberdaya material sehingga tercipta kepuasan manusia dan memungkinkan mereka menjalankan perintah Allah dan norma yang ada dalam masyarakat. ${ }^{54}$

Lebih lanjut Abd. Mannan menyebutkan bahwa ekonomi Islam merupakan ilmu pengetahuan sosial yang mempelajari masalah-masalah ekonomi rakyat yang diilhami oleh nilai-nilai Islam. ${ }^{55}$ Sedangkan M.M. Metwally mendefisikannya sebagai ilmu yang mempelajari prilaku muslim (yang beriman) dalam suatu masyarakat Islam yang mengikuti al-Qur'an, Hadis, Ijma, dan qiyas. ${ }^{56}$

Sayid Haidar Naqvi memandang ekonomi Islam lebih ditekankan sebagai sains yang bertugas menyibak permasalahan-permasalahan manusia dalam mengimplementasikan ajaran Islam dalam perekonomian. ${ }^{57}$ Sementara Umar Chapra berpandangan lain, baginya ekonomi Islam merupakan suatu cabang pengetahuan yang membantu merealisasikan kesejahteraan manusia melalui suatu alokasi dan distribusi sumber-sumber daya langka yang seirama dengan maqaaShid al-syarii' ah, tanpa mengekang kebebasan individu, menciptakan ketidakseimbangan makro ekonomi dan ekologi yang berkepanjangan atau melemahkan solidaritas keluarga dan sosial serta jaringan moral masyarakat. ${ }^{58}$ Hal ini sejalan dengan pendapat Louis Cantori yang menyatakan bahwa ekonomi Islam sebagai suatu upaya untuk memformulasikan suatu ilmu ekonomi yang berorientasi pada manusia dan masyarakat yang tidak mengakui individualisme yang berlebihan. ${ }^{59}$

Dalam politik ekonomi Islam manusia dipandang sebagai subyek bukan sebagai obyek. Sehingga terdapat konsekwensi logis adanya jaminan tercapainya pemenuhan semua kebutuhan primer (al-daruuriyah) tiap individu secara menyeluruh. Hal ini juga dimungkinkan adanya kemampuan setiap individu untuk memenuhi kebutuhan sekunder (al-haajiyat) dan tersiernya (al-tahsiiniyat) masing-masing sesuai dengan taraf hidup dan kadar kemampuan yang dimilki. ${ }^{60}$

Konsep Ad-daruurah dalam pandangan Az-Zuhaili merupakan suatu keadaan dimana seseorang mengalami kesulitan untuk menghindari kerugian bahkan bahaya yang dapat mengancam jiwa, harta, akal, kehormatan dan lain sebagianya. Namun demikian Az-Zuhaili memberikan batasan-batasan tertentu diantaranya darurat yang ia maksud tidak bertentangan dengan nilainilai keadilan, amanah (trust, kepercayaan), menolak kemadaratan, situasi daruratpun tidak terbatas dalam waktu tertentu. Lebih khusus ia menekankan adanya pernyataan resmi dari pemerintah bahwa Negara benar-benar dalam kondisi darurat (krisis yang akut) atau terdapat kepentingan umum yang sedang dihadapkan dengan suatu kerusakan dan bahaya laten yang harus dilawan secara bersama-sama.

Sedangkan al-haajah menurutnya merupakan kebutuhan dan/atau kepentingan baik menyangkut kepentingfan individu, kelompok maupun kepentingan masyarakat umum yang apabila tidak dapat dipenuhi maka akan dihadapkan dengan kesulitan dan kesusahan yang lebih fatal. Adapun

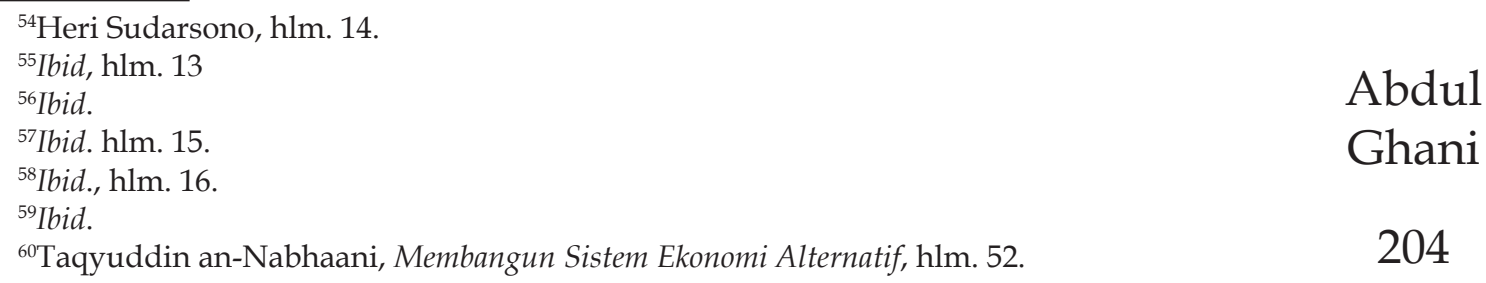


riba dalam pemikiran Az-Zuhaili merupakan lebihan harta dalam pertukaran suatu harta dengan harta yang lain tanpa disertai pengganti.

Baik ad-daruurah maupun al-haajah keduanya dapat dijadikan sebagai sarana legitimasi (pembenaran) dalam melakukan pelanggaran agama baik dalam bidang ekonomi, politik, social dan lain sebagainya dengan tidak mengabaikan batasan-batasan tertentu.

Dengan memperhatikan konsep ad-daruurah dan al-haajah yang dikemukakan Az-Zuhaili tersebut jika dikaitkan dengan konsep riba yang merupakan bagian dari komponen ekonomi terdapat benang merah antara ad-daruurah dengan al-haajah, yaitu; menegakkan prinsip keadilan ('adalah) atau keseimbangan (tawassut), upaya perlindungan terhadap tujuan-tujuan syara' (maqaaShid asy-syarii'ah al-khamsah) dan adanya kepentingan untuk kesejahteraan universal. Hal ini mengindikasikan adanya relevansi dengan sistem ekonomi Islam yang telah berjalan beberapa tahun.

Telah terdapat kesepakatan ulama dalam berbagai madzhab bahwa hukum riba adalah haram meski dalam perkembangannya terdapat perdebatan. Namun demikian mengacu pada kaidah-kaidah fikih khususnya yang berkaitan dengan konsep ad-daruurah dan al-haajah, az-Zuhaili memperbolehkan riba jika dihadapkan dengan kondisi memerlukannya (al-haajah) dan terpaksa untuk melakukannya (ad-daruurah) jika tidak ada alternatif lain dalam sistem perekonomian. Namun demikian az-Zuhaili tidak sampai menetapkan bahwa hukum riba adalah halal.

Konsep pemikiran demikian memberikan nuansa baru dalam sistem perekonomian kontemporer khsususnya sistem perekonomian Islam. Hal ini akan semakin jelas dilihat dalam diskusi berikut:

\section{Mendorong proses aktualisasi perbankan Islam dalam system perekonomian}

Sebagaimana diketahui hingga awal abad ke-20, perbankan Islam yang dalam diskusi ini disebut bank syari'ah hanya merupakan diskusi teoritis. Belum ada langkah nyata yang memungkinkan untuk mengimplementasikan gagasan tersebut. Padahal telah muncul kesadaran bahwa bank Islam merupakan solusi masalah ekonomi untuk mewujudkan kesejahteraan sosial yang bebas dari bunga/riba. Aktualisasi bank syari'ah seolah terganjal oleh cepatnya perkembangan bank konvensional yang ada saat ini.

Gagasan untuk mewujudkan bank syari'ah, semakin menguat dan mengkristal setelah gagasan tersebut dibicarakan dalam pertemuan menteri luar negeri Negara-negara anggota OKI di Karaci Pakistan pada tahun $1970 .{ }^{61}$ Dalam konferensi tersebut diputuskan perlunya membentuk suatu lembaga keuangan yang disebut Islamic Development Bank (IDB). Pada tanggal 23 April 1975 lembaga ini dinyatakan berdiri secara efektif setelah dipenuhinya semua ketentuan dalam anggaran dasar mengenai penyerahan instrument of ratification oleh Negara-negara anggota yang pada saat itu berjumlah 22 negara termasuk Indonesia. Munculnya upaya mendirikan lembaga IDB ini didasarkan atas pemahaman bahwa bunga bank yang ditimbulkan dari transaksi pinjam-meminjam di bank konvensional adalah riba, sebagaimana dilarang dalam Islam. ${ }^{62}$

Adh-Dharuurah Wa AlHaajiah 205
${ }^{61}$ Muhammad Syafi'I Antonio, selanjutnya disebut Antonio, Bank Syari'ah Bagi Bankir Dan Praktisi Keuangan (ttp: Dar al-Ittiba', 1999), Karnaen Perwata Atmadja, Muhamad Syafi'i Natonio, Apa dan Bagaimana Bank Islam (Yogyakarta: Dana Bhakti Wakaf, 1992), hlm. 58 ${ }^{62}$ Muhammad Zuhri, Riba,...,hlm. 155. 
Berdirinya IDB ini telah memotivasi banyak Negara Islam untuk mendirikan lembaga keuangan syari'ah. Untuk itu, kontselasi IDB pun bekerja keras menyiapkan panduan tentang pendirian peraturan dan pengawasan bank syariah. Pada akhir tahun 1970-an dan memasuki awal 1980-an bankbank syariah muncul di beberapa negara Islam seperti Mesir, Sudan, Pakistan, Iran, Malaysia dan lain sebagainya. ${ }^{63}$

Bank Islam yang berdiri di Indonesia disebut bank syariah merupakan lembaga keuangan yang usaha pokoknya memberikan kredit dan jasa-jasa dalam lalu lintas pembayaran serta peredaran uang yang pengoperasiannya disesuaikan dengan prinsip-prinsip syari' ah Islam. ${ }^{64}$ Didirikanya bank Islam pada dasarnya untuk mempromosikan dan mengembangkan aplikasi dari prinsip-prinsip Islam_syariah_, dan tradisinya dalam transaksi keuangan, perbankan dan bisnishbisnis lain yang terkait. Prinsip utama dalam aktifitas perekonomian Islam adalah:

Larangan riba

Perekonomian dijalankan sesuai dengan asas kegunaan (utility, manf' aat), ${ }^{65}$ yakni kemampuan suatu barang untuk memuaskan kebutuhan manusia. Memiliki nilai-nilai kemanusiaan ${ }^{66}$ yakni tujuan ekonomi Islam menciptakan manusia yang aman dan sejahtera; dan kebebasan, ${ }^{67}$ yakni bebas memiliki, memelihara, dan membelanjakan harta.

Menunaikan zakat

Sebagai pengganti dari sistem bunga ditawarkan sistem mudlarabah

Syafi'i Antonio menambahkan prinsip lain seperti:

Menghapuskan monopoli

Menjamin hak dan kesempatan setiap orang aktif dalam proses ekonomi baik produksi,distribusi, sirkulasi, maupun konsumsi

Menjamin terpenuhinya kebutuhan setiap individu

Terlaksananya jaminan sosial

Jika prinsip-prinsip tersebut dikomunikasikan dengan pemikiran AzZuhaili tentang titik temu antara konsep ad-daruurah wa al-haajah dalam kaitannya dengan riba maka akan terlihat poin 1, 4, 5 sebagai representasi dari nilai-nilai keadilan ('adalah); point 3, dan 6 merepresentasikan prinsip upaya perlindungan terhadap maqaaShid asy-syarii'ah; point 2, 7, 8 dan 9 merepresentasikan kepentingan universal.

Kalangan ekonom muslim telah menyepakati bahwa untuk mengganti system bunga yang beroperasi di dunia perbankan konvensioanl, diterapkan system profit and los sharing (mudarabah, bagi hasil). Karena menurut mereka keunggulan sistem mudlarabah dapat dirasakan oleh semua kalangan baik

\footnotetext{
${ }^{63}$ Antonio, Bank Syariah , hlm. 60, Mislanya The Nassar Social Bank (1971), The Islamic Dvelopment Bank (1975), The Dubai Islamic (1975), The Faisal Islamic Bank of Egyipt (1977), The Faisal Islamic Bank of Sudan ((1977), The Kwait Finance House (1977), The Bahrain Islamic Bank ( 1979), dan The Internasional Islamic Bank for Investmen and Develoopment (1980), lihat Abdullah Sa'eed, hlm. 15.

${ }^{64}$ Warkum Sumitro, Asas-asas Perbankan Islam dan lembaga terait (BMI dan Takaful) di Indonesia (Jakarta: Raja Grafindo Persada, 1996), hlm. 5.

${ }^{65}$ Taqyuddin an-Nabhaani, Membangun System Ekonomi Alternatif, hlm. 48.

${ }^{66}$ Yuusuf al-Qardhaawi, Norma Dan Etika Ekonomi Islam, alih bahasa Zainal Arifin (Jakarta: Gema Insani Press, 1995), hlm. 57.

${ }^{67}$ Ibid., hlm. 203-209.
}

Abdul
Ghani

206

JURNAL EKONOMI SYARIAH INDONESIA, Volume V, No.2 Desember 2015 
kalangan muslim maupun non muslim. ${ }^{68}$ Salah satu produk perbankan yang mengacu pada prinsip tersebut adalah akad kerja sama usaha antara dua pihak dimana pihak pertama (Shaahib al-maal/investor) menyediakan seluruh modal. Sedangkan pihak lainnya menjadi pengelola. Laba usaha secara mudlarabah dibagi menurut kesepakatan yang tertuang dalam kontrak. Sedangkan kerugian akan ditanggung sendiri oleh pemilik modal (investor). ${ }^{69}$ Disebut mudaarabah karena pelakunya berkelana dimana-mana untuk mendapatkan laba. ${ }^{70}$ Transaksi ini telah dikenal sebelum Islam. Contoh yang biasa dikemukakan dalam kasus ini adalah kerjasama Nabi dengan khadijah dalam kegiatan bisnis, dimana Nabi sebagai pekerja. Sedangkan Khadijah sebagai investor sebelum terjadi perkawinan diantara mereka.

Istilah mudaarabah dikenal Hanafiyah, Hanabilah dan Zaidiyah. Sedangkan dikalangan Syafi'iyah dan Malikiyah. Transaksi ini dikenal dengan qiraad. ${ }^{71}$ Menurut Ibnu Taimiyah para ahli hukum Islam menyatakan keabsahan mudaarabah berdasarkan riwayat yang disandarkan kepada beberapa orang sahabat. Tetapi tidak ada satupun hadis yang otentik tentang mudaarabah ini yang disandarkan kepada Nabi SAW. ${ }^{72}$ Ibnu Hazm (w. 456 /1064). Pendiri madzhab zaahiri, menyatakan setiap pasal fikih mempunyai dasar dalam alQur'an dan Sunnah kecuali mudaarabah. Menurutnya kita tidak menemukan dasar apapun mengenai itu. ${ }^{73}$ Menurut Syarakhshi (w. 483/1090), ahli hukum Hanafiyah, mudaarabah dibolehkan sebab orang-orang menyebutkan dan membutuhkan (haajah) kontrak jenis ini. ${ }^{74}$ Ibnu Rusyd (w. 595 / 1198), ahli hukum Malikiyah, menganggap mudlaraah sebagai konsesi khusus. ${ }^{75}$ Meskipun tidak secara eksplisit ditujukan dalam al-Qur' an dan ashSunnah, mudaarabah adalah sebuah tradisi yang dibolehkan dan dipraktekkan oleh orang Islam. Asosiasi komersial ini muncul secara kontinyu sejak periode awal Islam. ${ }^{76}$ Melihat perkembangan perekonomian sekarang ini sistem mudarabah menjadi suatu kebutuhan (hajah) tersendiri. Bahkan pada kondisi tertentu perbankan-perbankan Islam dimungkinkan harus menggunakan system mudarabah. Hal ini dimaksudkan untuk mengimbangi lajunya sistem bunga yang marak beroperasi di dunia perbankan konvensional.

Sebagaimana diketahui bahwa kerugian yang timbul dari usaha mudlarabah di tanggung oleh pemilik modal. Jika demikian halnya, karena bank sebagai pihak pemberi modal, maka berdasarkan prinsip ini jika terjadi

${ }^{68}$ Warkum Sumitro, Asas-asas Perbankan Islam dan Lembaga-lembaga (BAMUI dan MUI) Terkait di Indonesia (Jakarta: Raja Grafindo Persada, 1997), hlm. 49.

${ }^{69}$ Abdullah Sa'eed, Islamic Banking, hlm. 51, M. Umar Chapra, Towards......44 - 45. Perseroan tersebut sama dengan wakalah, dimana hkum orangyang menjadi tidak bias menanggung (kerugian), Sehingga kerugian tersebut hanya ditanggung oleh pihak yang mewakilkan saja, lihat Taqiyuddin an-Nabhani, an-Nizhaam al-Iqtishaadi fi al-Islaami, terj. M. Maghfur Wachid, Membangun Sistem Ekonomi Alternatif Perspektif Islam (Surabaya: Risalah Gusti, 1999), hlm. 161.

${ }^{70}$ Muhammad Syarbaini, Mugni al-Muhtaaj (Beirut: Dar al-Kutub al-'Ilmiyah, 2000), II: 474, lihat juga Al-Jaazirii, al-Figh 'ala al-Maz^ahib al-Arba'ah, III: 34.

${ }^{71}$ Muhammad Zuhri, Riba, hlm. 160.

${ }^{72}$ Muhammad Zuhri, Riba, hlm. 60, bandingkan dengan an-Nabhani, an-Nizham...., hlm. 160.

Adh-Dharuu-
rah Wa Al-
Haajiah
207

${ }^{73}$ Ibnu Taimiyah, Majmuu' Fataawaa, ......, xxix: hlm. 101, Abdullah Saeed, Islamic Banking..., hlm. 52.

${ }^{74}$ Muhammad Bin Ali bin Muhammad asy-Syaukani, Nailul Awt\{aar, (Kairo : Maktabah Islamiyah, t.t), V: 267,

${ }^{75}$ Syamsuddin al-Syarakhsi, Kitaab al-Mabsuut (Istambul: Dar al-Da'wa, 1983), XXII: 19.

${ }^{76} \mathrm{Ibnu}$ Rusyd, Bidaayat al-Mujtahid, II: 178. 
kerugian banklah yang menanggungnya. Sedangkan pihak pengelola dana (mudaarib) hanya rugi dari segi waktu, tenaga dan upah yang tidak didapatkan. Tetapi kemungkinan tersebut hanya teoritis belaka, baik dalam latar belakang ekonomi maupun empiris. Hal ini karena bank telah memberikan pinjaman modal kepada pengusaha lain yang berhasil baik berbentuk mudlarabah maupun lainnya. Karenanya kerugian dapat ditutup dari keuntungan tersebut. ${ }^{77}$

Dalam perseroan mudaarabah, pihak pemodal/investor dalam hal ini bank_tidak diperbolehkan ikut bekerja dengan pengelolanya. Jika hal itu dijadikan syarat, maka syarat tersebut tidak sah. Sebab pemodal_investor_ tidak berhak mengelola harta yang telah dilebur dalam perseroannya. Walaupun demikian, pengelola (mudaarib) tetap terikat dengan kontrak yang telah disepakati dengan pemodal, ia tidak boleh menyimpang dari kesepakatan tersebut. Dalam hubungannya dengan perbankan, keberhasilan peminjam menjadi tolok ukur untuk menilai konduite mereka. Peluang untuk mendapatkan pinjaman berikutnya ada pada mereka yang berhasil. Karena prospek usaha menjadi ukuran kepercayaan dari pihak bank, maka penataanya berjalan ketat, agar kemungkinan kerugian dapat diantisipasi. Dengan demikian dalam praktek mudlarabah tanggungjawab moral, kerjasama, saling percaya, kejujuran dan amanah diantara keduanya (mudaarib dan Shaahibul maal) lebih diutamakan. Memperhatikan praktek mudlarabah tersebut maka sistem bunga pada bank konvensional dapat dihindari.

\section{Meneralisir sikap ekstrim dan apriori terhadap operasionalisasi perbankan konvensional.}

Bank konvensional yang kita kenal saat ini dalam perkembangannya telah melewati sejarah yang panjang. Di belahan negeri Timur Tengah hingga Asia kecil (Turki) pada 5000 tahun sebelum masehi, bangsa sumeria telah mengenal kegiatan perbankan. Hal yang sama juga terjadi pada bangsa Babylonia, mereka melakukan aktifitas perbankan seperti pinjam meminjam, pengadaan perjanjian kredit dan sebagainya. ${ }^{78}$ Sedangkan pada belahan dunia eropa dan afrika kegiatan perbankan berlangsung sejak 2500 tahun sebelum masehi dalam masyarakat Mesir purba, Yunani kuno dan Romawi. ${ }^{79}$

Sementara yang lain membagi perkembangan perbankan konvensional kepada empat fase; pertama, sebelum tahun 5000; kedua, antaratahun 500 1500; ketiga, tahun 1550 -1750; keempat, antara tahun 1750 - sekarang. ${ }^{80}$

Ketika orang Islam sudah mulai kontak dengan bank, lembaga ini sudah berada pada kondisi yang maju dan modern. Karena itu persoalan-persoalan yang terkait dengan bank khususnya mengenai bunga, tergolong baru dalam kegiatan hukum Islam. Ia tidak dibicarakan dalam buku-buku tafsir dan fikih-fikih klasik.

\footnotetext{
${ }^{77}$ Umar misalnya pernah memberikan harta bagian anak yatim dengan system mudarabah, Usman bin Affan juga pernah memberikan harta kepada seseorang dengan system mudarabah, lihat an-Nabhani, an-Nizhaam, hlm. 81, 162.

${ }^{78}$ Muhammad Nejatullah Siddiqi, Issues in Silamic Banking (London: The Islamic Foundation, 1983), hlm. 24.

${ }^{79}$ Thomas Suyatno dkk, Kelembagaan Perbankan (Jakarta: Gramedia, 1987), hlm.12.

${ }^{80}$ Hasan Sadeli, ed. Ensiklopedi Indoesia (Jakarta: PT. Ikhtiar Baru Van Hoeve, 1966), hlm. 394. lihat juga Sutatwo Hadiwigeno, dkk, Lembaga Keuangan di Bank (Yogyakarta: UGM, 1984), hlm. 151- 17.
}

Abdul

Ghani

208

JURNAL EKONOMI SYARIAH INDONESIA, Volume V, No.2 Desember 2015 
Para ulama mutaqaddimin maupun mutaakhirin sepakat mengenai keharaman riba. Perbedaan muncul dikalangan ulama mutaakhirin (abad modern), ketika konsep riba dikaitkan dengan persoalan-persoalan perbankan, yang dalam melakukan aktifitasnya menggunakan sistem bunga. Persoalan muncul apakah bunga yang diberikan bank kepada pemasok modal (shahib al-mal) dan yang diberikan kepada debitur termasuk riba atau tidak?. Dalam menyikapi persoalan tersebut ada dua pandangan yang berbeda yakni modernis dan neo-revivalis. Kalangan modernis seperti Afzalurrahman (1964), Muhammad As'ad (1989), Sa'id an-Najjar (1989), Abd. Mun'im an-Na'im (1989) menekankan aspek moral dalam memahami pelarangan riba dan mengesampingkan legal formal riba itu sendiri. Menurut mereka alasan larangan riba adalah ketidakadilan, sesuai dengan pernyataan al-Qur'an:

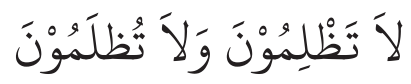

Pandangan tersebut menurut mereka juga ditemukan dalam beberapa karya para sarjana terdahulu seperti al-Razi, Ibnu al-Qayim dan Ibnu Taimiyah. ${ }^{81}$ Maka dari itu riba (usury) dibedakan dengan bunga (interest). Beberapa pandangan modernis mengenai bunga bank yang terkait dengan persoalan riba adalah:

Pertama: kebutuhan (al-haajah, requirement) sebagai alasan kebolehan bunga yang ringan. Sanhuri sebagai pengikut al-Jauziyah telah berusaha membedakan beberapa bentuk riba yang disebutkan dalam literatur, yakni; ribaa al-jaahiliyah (pre Islamic riba), ribaa an-nasii' ah (riba of deferment), ribaa al-fadl (riba of increase) dan ribaa al-qard (riba of loans). Sanhuri menegaskan, bahwa larangan terhadap semua bentuk riba sudah menjadi norma, sekalipun tingkat larangan tersebut berfariasi. Karena alasan ini praktek riba tidak sah kecuali dalam kondisi daruurah (emergency and necessity), atau haajah (need and requirement). Menurutnya ribaa al-jaahiliyah adalah bentuk riba yang paling buruk dikenal saat itu dan bunga (interest) termasuk kategori ini yang dilarang tanpa kualifikasi. ${ }^{82}$ Adapun riba nasii'ah, fadl, qard dilarang untuk mengantisipasi terjadinya ribaa al-jaahiliyah. Ketiganya mungkin diperbolehkan secara temporal dalam konteks haajah..

Sanhuri berpandangan bunga yang dikenal sekarang termasuk riba jahiliyah yang tidak ada dispensasi sekalipun dalam kondisi daruurah atau haajah. Tidak demikian halnya dengan 3 jenis lainnya. Meskipun Sanhuri mengaku sebagai pengikut Ibnu al-Qayyim dalam kasus ini ia berbeda dengannya dimana yang terakhir ini al-Jauziyah berpendapat dalam kondisi darurat riba jali bisa ditolerir. Sedangkan riba khafi (fadl) dibolehkan dalam kondisi membutuhkan (haajah.). Demikian pula az-Zuhaili secara umum sependapat dengan al-Jauziyah dengan mengatakan riba diperbolehkan dengan alasan daruurah dan haajah. Namun di satu sisi Ia juga sepaham dengan Abu Zahrah yang memberikan porsi sempit terhadap kebolehan riba dengan alasan daruurah dan haajah dalam konteks perekonomian modern saat ini.

Kedua, pinjaman konsumtif/produktif. Doualibi politikus kontemporer syiria membedakan antara pinjaman konsumtif dengan produktif. Dibolehkan bunga pada pinjaman produktif dan dilarang pada pinjaman konsumtif.

Adh-Dharuurah Wa Al-

Haajjah 209
${ }^{81}$ Abdullah Sa'eed, Islamic Banking...., hlm. 41.

${ }^{82} \mathrm{Abd}$. Razak Sanhuri, selanjutnya disebut Sanhuri, Mashaadir al-Haq fii al-Fiqh al-Islaami, (Beirut: al-Majma' al-' Arabi al-Islami, 1967), III: 241-242. Abdullah Sa'eed, Islamic Banking..., hlm. 43 - 44 . 
Hal ini katanya, didasarkan pada ayat-ayat al-Qur'an yang mengaitkan riba dalam mengurangi beban fakir, miskin, du' afa, dan orang yang tidak mampu melunasi pinjaman. Karena itu menurtunya, larangan al-Qur'an dikaitkan pada pinjaman konsumtif. ${ }^{83}$

Kritik terhadap pandangan tersebut dikemukakan oleh Abu Zahrah. Menurutnya tidak ada bukti apapun untuk menyanggah bahwa riba jahiliyah hanya diperbolehkan pada pinjaman konsumtif dan bukan pada pinjaman produktif. Sesungguhnya menurut riwayat pinjaman yang diberikan pada seseorang adalah pinjaman produktif. Situasi orang-orang arab, posisi Makkah, dan perdagangan orang-orang Quraisy, semuanya menegaskan bahwa pinjaman diperuntukkan bagi kepentingan produksi, bukan tujuan konsumsi. ${ }^{84}$ Jadi ayat-ayat al-Qur' an yang menekankan hanya mengembalikan pinjaman pokok bagi yang tidak mampu bukan berarti mengacu pada pinjaman konsumtif, tetapi mengacu pada pinjaman produktif dimana debitur menjalani kerugian sehingga tidak mampu mengembalikan modal pokoknya.

Nampaknya az-Zuhaili sebagai murid Abu Zahrah juga menyanggah pandangan adanya klasifikasi riba dalam pinjaman produktif dan pinjaman konsumtif. Sebelumnya ia menyebutkan bahwa hukum syara' dibentuk berdasarkan 'illat hukum yang kuat dan pasti (al-'illat al-mundabitah) tidak berdasarkan pada hikmah yang tidak mudah untuk dirasionalisasikan (alhikmah al-mudtaribah al-mukhtalafah). ${ }^{85}$ Sementara riba bagi az-Zuhaili merupakan permasalahan hukum yang berhubungan dengan hikmah. Dalam riba sarat dengan unsur eksploitasi dan ketidakadilan yang bertentangan dengan prinsip maqaaShid asy-syarii'ah.

Ketiga, individual/institusi. Sebagian sarjana megatakan bahwa larangan riba hanya berlaku pada individu bukan pada bunga badan hukum seperti, perusahaan-perusahaan baik dan instansi-instansi pemerintah. Pandangan ini juga mengekspresikan bahwa menerima bunga/interest, oleh seseorang dari badan hukum seperti bank tidak dilarang sebab individu tidak dapat mengeksploitasi organisasi besar seperti bank. ${ }^{86}$

Kritik terhadap argumen ini bahwa hukum Islam tidak membedakan kesejahteraan yang diperoleh individu maupun institusi. Seluruh lembaga perusahaan dan pemerintah secara otomatis merepresentasikan individuindividu. Bahkan institusi dapat mengeksploitasi sebagaimana individu, alQur'an sendiri tidak membedakan antara sebuah lembaga dengan individu berkaitan dengan riba.

Keempat, pandangan lain membedakan antara bunga (interest) dengan riba (usury). Pandangan ini dikemukakan oleh sarjana mesir Hafni Nasif dan Abd. Aziz Jawisy. Menurutnya berdasarkan al-Qur'an 3:130, riba yang disepakati keharamannya adalah bunga yang jumlahnya sama atau melebihi dari uang pokok. Sedangkan bunga yang kurang dari uang pokok masih dapat

${ }^{83}$ Abdullah Sa'eed, Islamic Banking....Muhammad Abu Zahrah, Buhuush Fii ar-Ribaa, hlm. 52-57.

${ }^{84}$ Muhammad Abu Zahrah, Buhuush Fii ar-Riba >, hlm. 53

${ }^{85}$ Terdapat perbedaan mendasar antara 'illat dengan hikmah. 'Illat bersifat konkrit, jelas dan pasti, sedangkan hikmah bersifat abstrak, nisbi dan tidak pasti. Dalam fikih pembentukan hokum hanya berdasarkan pada alasan yang jelas ('illat) dan tidak berdasarkan pada alasan yang tidak jelas (hikmah). Lihat Abd. Wahhab Khallaf, 'Ilmu Ushuul al-Figh, cet ke-12 (Beirut: Dar al-'Ilm, 1978), hlm. 63-67. Bandingkan dengan Abu Zahrah, Ushuul al-Figh, alih bahasa Fuad Falahuddin, cet ke 9 (Jakarta: Pustaka Firdaus, 2005), hlm. 364-369.

${ }^{86}$ Abdullah Sa'eed, Islamic Banking, hlm. 45

Abdul

Ghani

210

JURNAL EKONOMI SYARIAH INDONESIA, Volume V, No.2 Desember 2015 
diperdebatkan. ${ }^{87}$ Tampaknya pandangan ini mengadopsi undang-undang sipil Mesir yang menyatakan bahwa kreditur tidak boleh memungut bunga melebihi jumlah uang pokok.

Kelima, nominal/bunga ril (real interest), dalam ekonomi kontemporer harus diperhatikan apa yang disebut "inflasionary economy" yakni naiknya suku bunga akan mengoreksi kerugian yang diderita oleh kreditur yang disebabkan adanya inflasi, sebagaimana dikemukakan Syauqi Dunya. ${ }^{88}$

Memang bila dicermati secara seksama suku bunga yang diberikan bank kepada pemasok modal atau yang dipungut dari peminjam tidak bisa lepas dari masalah ril nilai mata uang yang dipinjamkan yang mengalami inflasi. Jika pemasok modal meminjamkan uangnya kepada bank kemudian disalurkan kepada pengusaha tanpa disertai imbalan apapun berarti bank dan pengusaha telah berbuat dzalim kepada Shaahib al-maal (pemilik modal). Semakin lama yang dipinjamkan, semakin turun nilai ril mata uang tersebut. Keadaan ini juga menciptakan ketidakadilan.

Ada dua alasan utama, mengapa bank memberikan bunga kepada pemasok dana: 1. dengan menyimpan uangnya di bank, penabung telah mengorbankan kesempatan atas keuntungan yang mungkin diperoleh demi pemakaian dana tersebut andaikata ia memanfaatkanya ${ }^{89} 2$. dengan menyimpan uang di bank penabung telah mengorbankan kesempatan pemakaian dana untuk keperluan konsumsi. Salah satu prinsip ekonomi adalah nilai uang sekarang lebih berharga dari pada nilainya kemudian. Dalam hal tabungan berjangka dengan menyimpan uang di bank, penabung mengorbankan sebagian likuiditasnya seperti berjaga-jaga menghadapi keperluan mendadak dan bahkan keperluan darurat.

Sementara itu kalangan neo-revivalis dalam memandnag riba lebih menekankan pada bentuk legal-formal sebagaimana telah dinyatakan dalam hukum Islam. Tokoh utama kelompok ini adalah al-Maududi dan Sayid Qutub telah mendiskusikan isu ketidakadilan dalam riba. Hasil kajian mereka menyimpulkan, bahwa ketidakadialn (zulm) adalah alasan utama dilarangnya riba. Maududi menyatakan " pendirian bahwa ketidakadilan menjadi alasan mengapa bunga pada pinjaman tidak diperbolehkan menunjukkkan semua bunga transaksi mengandung kekejaman, tetap didukung. ${ }^{90}$ Menurutnya riba adalah sejumlah suku bunga yang diterima kreditur dari debitur. Karena itu menurut kelompok neo-revivialis bunga bank adalah sama dengan riba. Chapra seorang pakar ekonomi Islam juga menegaskan riba mempunyai ma'na/arti dan tujuan yang sama dengan bunga. ${ }^{91}$ Afzalurrahman seorang pakar ekonomi Islam Pakistan, juga mengatakan " sesungguhnya kata riba dalam bahasa arab sebagian telah tercakup kata usury dalam bahasa inggris yang berarti suku bunga yang mencekik..". Sedangkan kata riba dalam bahasa Arab berarti tambahan, meskipun sedikit diatas jumlah uang yang dipinjamkan hingga mencakup sekaligus bunga dan riba. Menurutnya semua nas tentang pengharaman riba tidak hanya ditujukan terhadap bunga tinggi

\section{Adh-Dharuu- rah Wa Al- Haajjah 211}

\footnotetext{
${ }^{87}$ Abdullah Sa'eed, Islamic Banking, hlm. 46.

${ }^{88} \mathrm{Ibid}$. hlm. $46-47$.

${ }^{89}$ Teori ini dikemukakan oleh Adam Smith dalam bukunya "The Wealth of Nations" dan David Recardo dalam bukunya Principil of Political Ekonomi and Taxation. Teori ini dibantah oleh Lord Keynessyag mengatakan bunga tidak bias dianggap sebagai imbalan tabungan. Seseorang katanya, dapat menabung tanpa memberi pinjaman berbunga. Sebaliknya dapat menarik bunga tanpa melalui tabungan. Lihat Muslehuddin, Insurance, hlm. 131 - 132.

${ }^{90}$ Abdullah Sa' eed, Islamic Banking, hlm. 49.

${ }^{91}$ M. Umar Chapra, Towards..., hlm. 57.
} 
tetapi juga dimaksudkan untuk menghapus segala bentuk riba yang lain termasuk bunga bank..$^{92}$ Alasan yang mendasar pendirian kelompok ini adalah; Al-Qur'an secara jelas mengatakan bahwa beban pengembalian pinjaman hanyalah sebatas modal pokok. Dan tambahan yang ditentukan sebelumnya adalah riba. Uang haruslah bersih. Permintaan untuk memperoleh imbalan mendapatkan uang berada pada posisi beresiko. ${ }^{93}$

Dalam pandangan mereka pendirian ini didasarkan pada ayat al-Qur'an:

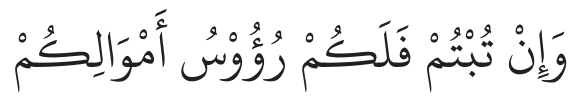

Terminologi ru'uusu amwaalikum mereka interpretasikan sebagai modal pokok, include di dalamnya segala sesuatu yang menjadi tambahan. ${ }^{94}$ Bagi mereka setiap tambahan pada modal pokok seberapapun kecilnya tambahan tersebut dikategorikan sebagai riba. Pandangan neo-revivalis tersebut dikokohkan dengan dikeluarkannya hasil konferensi Majma' al-Buhuuts al-Islaam (Konsul Kajian Islam Dunia) di Universits Al-Azhar, Kairo, Mei 1965 menetapkan bahwa pembungaan uang yang dilakukan oleh bankbank konvensional adalah haram. ${ }^{95}$ Berikutnya pada bulan Juli lahir pula pernyataan sikap bersama sejumlah ulama mesir yang berada di Makkah menolak fatwa mufti mesir yang membolehkan bunga bank. ${ }^{96}$ Pernyataan sikap tersebut ditanda tangani oleh ulama besar yang ada saat itu.

Dari uraian tersebut tampaknya perdebatan seputar bunga bank yang terkait dengan maslah riba belum akan berakhir. Bahkan kedua pendapat yang saling bertolak belakang antara modernis dengan neo-revivalis tersebut tidak akan berhenti.

Mencermati perdebatan tentang suku bunga bank tersebut, maka mengkomunikasikan konsepsi az-Zuhaili tentang ad-daruurah dan al-haajah berkenaan dengan riba dalam konteks ini menjadi sangat relevan. Karena teori ad-daruurah dan al-haajah yang dikemukakan az-Zuhaili menyentuh pada persoalan aktual_dalam hal ini riba bunga bank_ yang sedang hangat dibicarakan dan diperdebatkan dikalangan sarjana muslim khususnya bidang ekonomi syari'ah.

Konsep riba sendiri dalam pemikiran Az-Zuhaili tidak hanya dipahami berdasarkan pada nash atau teks, tetapi juga mengacu pada teori ad-daruurah dan al-haajah yang bersumber dari al-qawaa'id al-fighiyah. Artinya sekalipun bunga bank dianggap riba misalnya dan dikategorikan pada jenis riba jahiliyah (nasi'ah), yang menurut istilah Ibnu al-Qayyim disebut riba al-jali, masih bisa ditolerir. Karena disisi lain masyarakat sangat membutuhkan kehadiran bank, bahkan Negara secara keseluruhan. Karena fungsinya yang sangat fital sebagai lembaga pengumpul dana kepada masyarakat dan sangat berpengaruh terhadap perkembangan ekonomi suatu Negara. Masalahnya

${ }^{92}$ Afzalurrahman, Ekonomi Doktrines of Islam, alih bahasa Soeroyo Nasta'in, Doktrin Ekonomi Islam (Yogyakarta: PT. Dana BHakti Wakaf, 1996) 3: 85.

${ }^{93}$ Abdullah Sa'eed, Islamic Banking, hlm. 119.

${ }^{94} \mathrm{Ibid}$.

${ }^{95}$ diantara ulama -ulama besar yang lahir saat itu, Syeikh al-Azhar Muhammad Abuu Zahrah, Abdullaah Darraaz, Musht\{afaa Ahmad Zarqaa, Yuusuf al-Qardhaawi, dan lebih 300 ulama besar dunia lainnnya, lihat Antonio, Bank Syari'ah, hlm. 108.

${ }^{96}$ Untuk mengtehaui perbincangan lebih jauh mengenai alasan masing-masing yang membolehkan dan yang mengharamkan bunga bank, lihat Muhammad Abu Syahbah, Hululun..., hlm. 5 - 30, 135.

\section{Abdul Ghani} 212

JURNAL EKONOMI SYARIAH INDONESIA, Volume V, No.2 Desember 2015 
apakah sekarang masih bisa dikatakan darurat dalam melakukan transaksi dengan perbankan. Sementara bank Islam yang disebut-sebut sebagai bank alternative telah bermunculan diberbagai Negara termasuk Indonesia. AzZuhaili sejalan dengan pemikiran Abu Syahbah yang menyatakan alasan darurat tersebut tidak bisa dibenarkan karena Islam masih memiliki alternatif lain sebagai pengganti sistem ribawi tersebut yakni diantaranya qiradl atau mudlarabah. Alasan dlarurat hanya bisa diterima jka tidak ada alternatif lain. Sebailiknya jika ada alternative lain maka alasan tersebut tertolak. ${ }^{97}$

Akan tetapi seperti disinyalir oleh Timur Kuran berkaitan dengan bank Islam, bank yang bebas bunga menurutnya tidak sepenuhnya terbebas dari bunga. Hanya saja bentuknya disamarkan dan diberi baju Islam. Praktek-praktek bank Islam yang dikategorikan seperti itu antara lain bai' mu'ajjal. ${ }^{88}$ Sistem penggajian tetap yang diterapkan bank Islam juga menjadi sorotan Timur Kuran. Menurutnya dari sistem ini nampak bank Islam tidak sepenuhnya menganut sistem bagi hasil (profit and lost sharing). Karena menurutnya jika bank Islam menganut sistem bagi hasil dengan alasan menghindari bunga, seharusnya gaji karyawan juga diberikan sesuai dengan dengan jumlah keuntungan yang diperoleh bank, misalnya dalam hitungan perbulan. Artinya gaji karyawaan diberikan dengan gaji tidak tetap. Namun kenyatannya menurut Kuran para ekonom Islam tidak setuju dengan sistem penggajian tidak tetap ini. ${ }^{99}$ Dan kenyataan yang sedang berjalan seluruh perbankan Islam menganut sistem upah atau gaji tetap. Sekali lagi dalam perspektif Timur Kuran bank Islam masih memiliki karakter yang ambivalen (mendua) dalam menganut profit and lost sharing tersebut.

Dengan demikian pemikiran az-Zuhaili mengenai teori ad-daruurah dan al-haajah dalam kaitannya dengan riba dapat menetralisisr pendapat ekstrim yang ditujukan kepada bank konvensional. Bahkan melihat perkembangan bank Islam yang terkesan sangat lambat. Apa yang dikemukakan az-Zuhaili setiap transaksi dapat terbebas dari riba apabila mengakomodasi nilai keadilan yang diimplementasikan dalam bentuk menghindari eksploitasi, zulm, dan monopoli dapat menjadi tawaran baru dalam mengembangkan sistem ekonomi yang benar-benar Islami. Karena bagaimanapun juga eksploitasi, dzulm dan monopoli mengandung unsur kemadaratan yang harus dihindari dan juga dapat menghalangi terpenuhnya kebutuhan individu maupun masyarakat secara umum.

\section{KESIMPULAN}

Berdasarkan pembahasan pada bab-bab sebelumnya, maka dapat disimpulkan beberapa hal sebagai berikut:

Ad-daruurah dalam pandangan az-Zuhailii didefinisikan sebagai;

"Suatu keadaan bahaya atau kesulitan yang berlebihan yang disadari ataupun tidak disadari suatu saat akan mengancam kelangsungan hidup seseorang."

Hal ini jelas bertentangan dengan nilai-nilai maqaaShid asy-syarii'ah yang tercover didalamnya perlindungan terhadap jiwa, anggota tubuh, kehormatan, 'aqal, harta benda atau sejenisnya. Sehingga dalam kondisi

Adh-Dharuu-

rah Wa Al-
Haajjah
213

\footnotetext{
${ }^{97}$ Muhammad Abu Syahbah, Huluulun, hlm. 108 - 110.

${ }^{98}$ Timur Kuran, The Economic System in Contemporary Islamic Thought, Interpretation and Assesment dalam int, J. Midle East Studies 18, 1996, hlm. 156-157.

${ }^{99}$ Ibid. hlm. $156-158$.
}

JURNAL EKONOMI SYARIAH INDONESIA, Volume V, No.2 Desember 2015 
tersebut seseorang diperbolehkan melakukan perbuatan yang dilarang agama, dengan tujuan untuk menolak kemadlaratan yang diyakininya benarbenar akan terjadi. Kondisi darurat yang dimaksud mencakup segala aspek kehidupan.

Sedangkan makna al-haajah adalah keadaan seseorang yang telah sampai pada titik ketergantungan terhadap tindakan-tindakan yang dilarang agama. Sehingga dengan adanya faktor ketergantungan tersebut seseorang akan mengalami efek negatif bahkan terjadi kesulitan dalam hidup ketika tidak dapat meraih apa yang dibutuhkannya. Al-haajah dapat juga diartikan sebagai kebutuhan privat (al-haajah al-khaaShShah.) dan kebutuhan publik (al-haajah al-'aammah) yang mencakup kemaslahatan hidup semua manusia secara kesuluruhan yang meliputi bidang pertanian, perindustrian, perdagangan, politik, hukum dan lain sebagainya.

Sehingga terdapat perbedaan antara ad-daruurah dengan al-haajah, addaruurah berdasarkan atas perbuatan yang murni adanya tuntutan dan tidak memungkinkan untuk ditinggalkan. Sedangkan al-haajah berdasarkan atas kemudahan dan masih memungkinkan untuk ditinggalkan.

Pembahasan ad-daruurah selalu dikaitkan dengan term al-haajah. Secara teoritis az-Zuhaili memposisikan al-haajah sebagai turunan dari konsep addaruurah. Hal ini dapat dilihat dari pemetaan beliau tentang kaidah-kaidah yang berhubungan dengan konsep ad-daruurah. Dari delapan kaidah yang berhubungan dengan konsep ad-daruurah, hanya satu kaidah yang ia sebutkan sebagai landasan untuk melakukan pembahasan konsep al-haajah. Dengan konsep ad-daruurah dan al-haajah, az-Zuhaili masih dapat mentolerir larangan riba ketika tidak ditemukan sistem lain sebagai alternatif. Pandangan ini didasarkan pada dua kaidah pokok yakni;

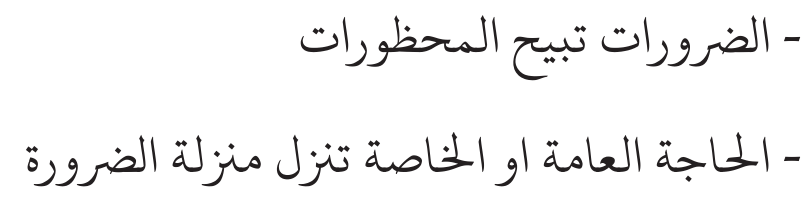

Konsepsi az-Zuhaili tentang ad-daruurah wa al-haajah berkaitan dengan riba jika dikomunikasikan dengan sistem perekonomian Islam terdapat relevansi dan memiliki peranan yang sangat signifikan. Secara khusus dalam bidang perbankan konsep ad-daruurah wa al-haajah dapat dijadikan sebagai modal dasar (basic main) dalam mendorong proses aktualisasi perbankan Islam dan menetralisir sikap ekstrim dan apriori terhadap operasionalisasi perbankan konvensional.

\section{DAFTAR PUSTAKA}

\section{Al-Qur'an/Tafsir}

Arabi, Abii Bakr Muh\{ammad bin 'Abdullaah Ibnu al-, 1967, Ahkaam alQur'aan, bagian I, cet ke-2, Kairo: Mausuu' ah al-Fiqh al-Islaami.

Ibnu Katsiir, 1997, Tafsiir al-Qur'aan al-'Aziim, juz II, cet ke-1, Beirut: Dar al-Fikr. JaShShaSh, 1993, Ahkaam al-Qur'aan, juz I, Beirut: Daar al-Kutub al-'Ilmiyah. Nawaawi, Muhammad Al-Jaawi, t.t., Maraahu Labiid at-Tafsiir an-Nawaawii, Surabaya: Al-Hidayah

Abdul
Ghani

214

JURNAL EKONOMI SYARIAH INDONESIA, Volume V, No.2 Desember 2015 
Qurtubi, al-, t.t., Tafsiir al-Qurtuubii al-Jaami' li Ahkaam al-Qur'aan, Jilid I, cet I, Kairo: Dar al-Sya'b.

Raazi, Al-Fakh al-, 1990, Tafsiir Al-Kabiir, juz III, Beirut: Daar al-Kutub al'Ilmiyah.

Ridaa, Muhammad Rasyiid, t.t., Tafsiir al-Qur'an al-Hakiim al-Syahiir Bi Tafsiir al-Mannaar, juz II, Bierut: Daar al-Fikr.

SHaabuunii, Alii aSh, t.t., Rawaai' al-Bayaan, Tafsiir A<yaat al-Ahkaam Min alQur'aan, jilid I, cet III, t.tp: Daar al-Fikr.

Suyuutii, Jalaaluddin 'Abd ar-Rahman bin Abii Bakr al-, t.t., Ad-Dur alMantsuur Fii at-Tafsiir al-Ma'tsuur, juz II, Beirut: Daar al-Kutub al'Ilmiyah.

Syanqiitii, Muhammad al-Amiin bin Muhammad bin al-Hakanii asy-, 1990, Adwaa al-Bayaan Fii I<daah al-Qur'aan bi al-Qur'aan, Juz I, Beirut: Daar al-Fikr.

Syaukaanii, Muhammad bin 'Alii bin Muhammad al-, t.t., Fath al-Qadiir, AlJamii' Baina Fanniiy ar-Riwaayah wa al-Diraayah Min 'Ilmi at-Tafsiir, juz I, Beirut: Daar al-Fikr.

Thabarii, Abuu Ja'far Muh\{ammad bin Jariir at-, 1999, Tafsiir at-Thabarii alMusammaa Jamii' al-Bayaan fii Ta'wiil al-Qur'aan, Jilid II, cet ke-3, Beirut: Dar al-Kutub al-'Ilmiyah.

Thabatabaa'i, Muhammad Husain al-, 1983, Al-Miizaan Fii Tafsiir al-Qur'aan al-Kariim, juz I, cet ke-5, Solo: Maktabah AS.

Wizaarah asy-Syu' uun al-Islaamiyah fii al-Mamlakah al-'Arabiyah, $1418 \mathrm{H}, \mathrm{Al}$ Qur'aan al-Karim wa Tarjamatu Ma'aanihii ilaa al-Lugah al-Induunisiyah, Saudi Arabia: Mujamma' Al Malik Li Thiba'at Al-Mushhaf.

Zuhailii, Wahbah az-, 1991, al-Tafsiir al-Muniir wa al-'Aqiidah wa asy-Syarii'ah wa al-Manhaj, Juz. I, 23, Damaskus: Daar al-Fikr al-Mu'aas\}irah. ,t.t., At-Tafsiir Al-Wajiiz, Beirut: Dar el Fikr.

\section{Al-Hadis}

Bukhaarii, Abii Abdullaah Muhammad bin Isma'iil al-, 1994, SHahiih alBukhaarii, 4 jilid, t.tp: Daar al-Fikr.

Ibnu Majah, 1996, Sunan Ibnu Maajah, Beirut: Daar al-Fikr.

Turmuzi, 1996, Sunan al-Turmuz, Beirut: Daar al-Fikr.

\section{Fiqih/Ushul Fiqih}

Abduh, 'Isa, 1978, Wadıu ar-Ribaa Fi al-Binaa al-IqtiShaady, Cet I, Kuwait: Dar al-Buhuts al-Ilmiyah.

Abdullah, Amin, 2004, Neo Ushul Figh; Menuju Ijtihad Kontekstual, cet ke1,Yogyakarta: Fak. Syari'ah IAIN Sunan Kalijaga.

Adh-Dharuu- Abu Sura'i, Abd Hadi,1993, Ar-Ribaa wa al-Quruud, alih bahasa Drs. M. Thalib, rah Wa AlSurabaya: Al-Ikhlas.

Haajiah 215

Abuu Zahrah, Muhammad, 1970, Buhuts fii ar-Ribaa, Cet I, t.tp: Daar al-Buhuuts al-'Ilmiyah. 
Antonio, Muhammad Syafi'I, 1992, Apa Dan Bagaimana Bank Islam, Yogyakarta: Dana Bhakti Wakaf.

'Asqalaanii, Syihaabuddiin Ibnu Hajar al-, 1990, Tahziib at-Tahziib, Beirut: Daar al-Fikr.

Badsyah, Muhammad Amin Amir, t.t., Taysiir at-Tahriir, II, Beirut: Dar al-Fikr. Chapra, M. Umar, Dr, 2000, Sistem Moneter Islam, Jakarta: Gema Insani Press.

Duwaisyi, Syaikh 'I<sa Bin Ibraahiim al-, 2002, Al-Buyuu' al-Jaaiz Minhaa wa al-Mamnuu', alih bahasa Ruslan Nurhadi, cet ke-1, Bogor: Daar Ibn Khuzaimah.

Dahlan, Abd. Azis, 2001. Ensiklopedi Hukum Islam, Jilid I, Jakarta: PT. Ichtiar Baru van Hoeve.

Hasballaah, 'Alii, 1971, UShuul at-Tasyrii' al-Islaamii, Mesir: Dar al-Ma'arif.

Ibnu Mubaarak, Jamiil Muhammad, 1988, Nazariyah ad-daruurah asy-Syar'iyah Huduuduhaa Wa Dhawaabituhaa, Kairo: Dar al-Wafi.

Ibnu Rusyd, t.t., Bidaayah al-Mujtahid Wa Nihaayah al-IqtiShaad, jilid II, Surabaya: Dar Ihya al- Kutub al-'Arabiyah.

Jauziyah, Ibnu Qayim al- Abuu 'Abdillaah Syamsuddiin Muhammad Ibn Abii Bakr, 1977, I'laam al-Muwaqqi'iin, jilid III, Beirut; Dar al-Fikr.

Jaziirii, 'Abd ar-Rahman al-, 2002, Kitaab al-Figh 'Alaa al-Mazaahib al-Arba'ah, cet 1, Beirut: Dar al-Fikr.

Kaafi, Ahmad al-, 2004, Al-Haajah asy-Syar'iyah Huduuduhaa wa Qawaa'iduhaa, Beirut: Dar al-Kutub al-'Ilmiyah.

Khafif, 'Ali al-, 1952, Asy-Syirkaat fii al-Fiqh al-Islaamy, al-Qaahirah: Mat \{ba'ah ashSunnah al-Muhammadiyah.

Khudaarii, Muhammad al-, t.t., Taariikh at-Tasyrii', Jeddah: Al-Haramain.

Lubis, Suhrawardi K, 2004, Hukum Ekonomi Islam, cet ke-3, Jakarta: Sinar Grafika.

Majlis Tinggi Urusan Keislaman, t.t., Mausuu'ah al-Figh al-Islaamiyah, juz XIV, Mesir: Al-Majlis al-Ala'laa Li al-Syu'uun al-Islaamiyah.

Mervyin Lewis dan Latifa el-Ghoud, 2003, Islamic Banking, alih bahasa Burhan Wirasubrata, Jakarta: Serambi.

MiShrii, Raafiq Yuunus al-, 1991, Al-Jaami' Fii Usuul ar-Ribaa, Damaskus: Dar al Qalam.

Nasution, Khoiruddin, 1996, Riba Dan Poligami, Sebuah Study Atas Pemikiran Muhammad 'Abduh, Yogyakarta: Pustaka Pelajar.

Qardaawii, Yuusuf, 2002, Fawaa'id al-Bunuuk Hiya ar-Ribaa al-Haraam, alih bahasa Dr. Setiawan Budi Utomo, Jakarta: Akbar Media Eka Sarana. 1995, Norma Dan Etika Ekonomi Islam, alih bahasa Zainal Arifin, Jakarta: Gema Insani Press.

Sa'id, Abdullah, 2004, Islamic Banking And Interest A Study Of The Prohibition OfRiba And Its Contemporary Interpretation, alih bahasa oleh M. Ufuqul Mubin, Jogjakarta: Pustaka Pelajar. 
Sudrasono, Heru, 2004, Konsep Ekonomi Islam Suatu Pengantar, cet I, Yogyakarta: Ekonisia.

Suyuutii, Jalaaluddin 'Abd ar-Rahman bin Abii Bakr ash, t.t., Al-Asybaah Wa an-Nazaair Fii al-Furuu', Semarang: Toha Putra.

Syaafi'i, 1990, Al-Um, 2 jilid, Beirut: Dar al-Fikr.

Syarbini, Muhammad asy-, t.t., Al-Iqnaa', II, Semarang: Toha Putra.

Syaatibii, Abii Ishaq Ibraahiim al-Lahmi al-, t.t., Al-Muwaafaqaat fii UShul alAhkaam, Juz II, (t.tp: Dar Al-Rasyad Al-Haditsah.

Syaerifii, Waalid Khaalid al-, 1990, Al-Madkhal Ilaa al-Maaliyah al- 'Ammah alIslaamiyah, Yordania: Dar al-Nafais.

Syafi'I, Rachmat, 1991, Ilmu Ushul Figh, Cet I, Bandung: Pustaka Setia.

Syarbaini, Muhammad, 1990, Mugnii al-Muhtaaj, Beirut: Daar al-Fikr.

Syaukaanii, Muhammad Bin 'Ali bin Muhammad al-, t.t., Nail al-Awtaar, Juz V, Kairo: Maktabah Islaamiyah.

Thariiqii, 'Abdullaah Ibn Muhammd al-, 1996, Al-Idtiraar Ilaa al-At'imah Wa al-Adwiyah al- Muharramaat, Jakarta: Pustaka 'Azzam.

Taimiyah, Ibnu, 1990, Majmuu' Fataawaa, Damaskus: Daar al-Fikr.

Wahyudi, Yudian, 2006, Ushul Fikih Vs Hermeneutika, Membaca Islam Dari Kanada, Yogyakarta: Pesantren Nawesea Press.

Zuhailii, Wahbah al-, 2004, Al-Figh al-Islaam Wa Adillatuhuu, 8 jilid, Damaskus: Daar al-Fikr. al-, 1982, Nazariah al-Dharuurah asy-Syar'iyah Muqaaranah Ma'a al-Qaanuun al-Wad'iy, Beirut: Muassasah ar-Risaalah. 1986, UShuul al-Figh al-Islaamii, 2 juz, Damaskus: Daar al-Fikr.

\section{Lain-Lain}

"Website Dr. Wahbah Zuhaili", http://www..Zuhayli.com.htm, akses 20 Februari 2007.

Al-Alussi, 1991, Ruuh al-Ma'aani, Juz III, Damaskus: Daar al-Fikr.

Amiruddin, S.H dan H. Zainal Asikin, S.H, S.U, 2004, Pengantar Metode Penelitian Hukum, Jakarta: PT. Raja Grafindo Persada.

Antonio, Muhammad Syafi'I, 1999, Bank Syari'ah Bagi Bankir Dan Praktisi Keuangan, ttp: Dar al-Ittiba'. 1999, Bank Syari'ah Wacana Ulama dan Cendikiawan, Jakarta: Tazkia Institut.

'Asqalaanii, Syihaabuddiin Ibnu Hajar al-, 1990, Tahziib at-Tahziib, Beirut: Daar al-Fikr, .

Bisri, Cik Hasan, 2003, Model Penelitian Fiqih, Jakarta: Prenada Media.

Chapra, M. Umar, 1983, Towards, London: The Islamic Foundation.

Adh-Dharuurah Wa Al-

Haajjah 217
Heru Nugroho, 2001, Uang Rentenir dan Hutang Piutang di Jawa, cet ke-1, Yogyakarta : Pustaka Pelajar. 
Hidayah, Nani, 2000, Riba dan Bunga Bank menurut Fazlurrahman, skripsi tidak diterbitkan, Fak. Syariah IAIN Sunan Kalijaga, Yogyakarta.

Hulliyah, Naning, 1999, Bank Dalam Pandangan Ulama Kontemporer, Studi PemikiranYusuf Qordlowi, skripsi tidak diterbitkan, Fak. Syariah IAIN Sunan Kalijaga, Yogyakarta.

Kuran, Timur, 1996, The Economic System in Contemporary Islamic Thought, Interpretation and Assesment dalam int, J. Midle East Studies 18.

Marzuki, MM, Drs, 2005, Metodologi Riset, Panduan Penelitian Bidang Bisnis Dan Sosial, cet I, Yogyakarta: Ekonisia.

Masri, S dan Sofian E, 1989, Metode Penelitian Survei, Jakarta: LP3ES.

Nabhaani, Taqyuddiin an-, 1999, An-Nizaam al-iqtiShaadi fii al-Islaam, alih bahasa Maghfur Wahid, cet ke-4, Surabaya: Risalah Gusti.

Nazir, Mohammad, 1985. Metode Penelitian, Jakarta: Ghalia Indonesia.

Nopirin, 1999, Ekonomi Internasional, Edisi 3, Yogyakarta: BPFE Yogyakarta.

Qardaawi, Yuusuf al-, 1995, Norma Dan Etika Ekonomi Islam, alih bahasa Zainal Arifin, Jakarta: Gema Insani Press.

Siddiqi, Muhammad Nejatullah, 1983, Issues in Silamic Banking, London: The Islamic Foundation.

Sumitro, Warkum, 1996, Asash Asas Perbankan Islam Dan Lembaga Tekrait (BMI dan Takaful ) di Indonesia, Jakarta: Raja Grafindo Persada.

Supena, Ilyas, 2002, Dekonstruksi dan Rekonstruksi Hukum Islam, Yogyakarta: Gama Media.

Suyatno, Thomas dkk, 1987, Kelembagaan Perbankan, Jakarta: Gramedia.

Syahbah, Muhammad Abuu, 1995, Huluul, Damaskus: Daar al-Fikr.

Syarakhsi, Syamsuddiin al-, 1983, Kitaab al-Mabsuut, XXII, Istambul: Dar alDa'wa.

Taimiyah, Ibn, 1990, Kitaab ar-Rad 'alaa al-Mantiqiyiin, Damaskus: Daar al-Fikr.

Zuhaili, Wahbah az-, 1996, al-Qur'an Paradigma Hukum dan Peradaban, terj. Muhammad Luqman Hakim dan Muhammad Fuad Hariri, Surabaya: Risalah Gusti.

Zuhri, Muhammad, 1999, Riba dalam Al-Qur'an dan Masalah Perbankan, Jakarta: PT. Raja Grafindo Persada. 